\title{
Human capital or signaling? Differences in skills distributions and the labor market disadvantage of less-educated adults across 21 countries
}

\author{
Jan Paul Heisig ${ }^{*}$, Maurice Gesthuizen ${ }^{+}$, and Heike Solga ${ }^{*}$ \\ * WZB Berlin Social Science Center \\ + Radboud University, Department of Sociology \\ $\sim$ Freie Universität Berlin, Institute of Sociology
}

December 9, 2016

\begin{abstract}
Less-educated adults bear the highest risk of labor market marginalization in all advanced economies, but the extent of their disadvantage differs considerably across countries. Exploiting unique data on the actual skills of adults from PIAAC 2011/12, we examine two prominent explanations for this cross-country variation. Human capital theory suggests that the marginalization of less-educated individuals reflects a lack of skills. The signaling explanation emphasizes the role of educational credentials as easy-to-observe proxies for skills and productivity. It suggests that the skills distribution of educational groups can affect their labor market position beyond any individual-level effect of skills by influencing the signaling value or "skills transparency" of educational credentials. Applying a two-step regression approach to a sample of 48,033 adults in 21 countries, we find support for both explanations. Consistent with human capital theory, literacy and numeracy skills are positively related to occupational status at the individual level and partly account for crossnational differences in the labor market disadvantage of less-educated adults. Yet, crosscountry variation remains considerable even after controlling for skills and further key observables. Consistent with the signaling account, country-level regressions show that the remaining variation is related to two direct measures of skills transparency: the aggregate skills differential between less- and intermediate-educated adults and the internal homogeneity of these groups. We also find that the labor market disadvantage of lesseducated adults increases with the vocational orientation of secondary education, presumably reflecting individual- and aggregate-level effects of occupation-specific skills, which were not assessed in PIAAC.
\end{abstract}




\section{INTRODUCTION}

It is well-established that educational degrees are positively associated with labor market outcomes such as employment rates, occupational status, or wages. In particular, many studies show that less-educated adults, that is, adults who did not complete upper-secondary education, bear the highest risk of labor market marginalization in all advanced economies (e.g., Abrassart 2013; Gesthuizen, Solga, and Künster 2011). This disadvantage results in elevated poverty risks (e.g., Green, Preston, and Janmaat 2006), which is one of the reasons why the "social investment state" approach (Giddens 2000) seeks to combat poverty by improving the employment opportunities of poor adults rather than through social transfers (e.g., Crouch, Finegold, and Sako 1999; Solga 2014). The precise extent of less-educated adults' labor market disadvantage differs considerably across countries, however (Abrassart 2013; Andersen and Van de Werfhorst 2010; Bol and Van de Werfhorst 2011; Gesthuizen, Solga, and Künster 2011; Shavit and Müller 1998). A better understanding of these country differences is important for designing policies that effectively improve the employment opportunities of less-educated adults and thereby reduce their poverty risks.

In this paper, we focus on two prominent explanations for their labor market disadvantage: According to the human capital explanation, less-educated individuals tend to have lower skills and to be less productive than individuals with higher qualifications. This productivity disadvantage translates into lower wages and occupational attainment and higher unemployment (e.g., Abrassart 2013; Murnane, Willett, and Levy 1995). A second account, the signaling explanation, emphasizes the role of educational credentials as easy-to-observe proxies for skills and productivity. The key idea is that individual skills are difficult to ascertain and that employers therefore use educational attainment as a (noisy) signal of actual skills and/or trainability (Spence 1973; Weiss 1995).

Both explanations suggest that country differences in the skills gap between less-educated and better-educated workers can explain country differences in their labor market position, but the underlying mechanisms differ. In the human capital framework, the reason is that individuals' actual skills are rewarded on the labor market. The signaling account, by contrast, suggests that the skills differential between less-educated and better-educated adults should have an independent effect above and beyond the direct, individual-level effect of skills. As this skills differential increases, employers should become more likely to preselect applicants 
on the basis of formal qualifications, that is, to statistically discriminate against less-educated adults.

A crucial limitation in testing and adjudicating between these two explanations has been a lack of high-quality and cross-nationally comparable information on the actual skills of working-age individuals. In particular, many previous studies have taken a rather indirect approach and focused on the role of secondary education systems in accounting for crossnational differences in the labor market disadvantage of the less-educated and in returns to educational attainment more broadly. This line of research has found that labor market returns to educational degrees increase with the extent of external differentiation (i.e., ability-related tracking) and vocational orientation (i.e., emphasis on occupation-specific skills) in secondary education (e.g., Andersen and Van de Werfhorst 2010; Bol and Van de Werfhorst 2011; Shavit and Müller 1998).

The prevailing interpretation of this result is that external differentiation and vocational orientation promote "skills transparency" with respect to general and occupation-specific skills, respectively. In other words, these institutional features strengthen the link between formal qualifications and actual skills (Andersen and Van de Werfhorst 2010). So far, however, there is very little direct evidence that country differences in returns to educational degrees are due to differences in skills transparency, although Heisig and Solga's (2015) recent finding that external differentiation raises the skills differential between adults with low and intermediate formal qualifications is consistent with this interpretation. Moreover, even if one accepts the premise that education systems are linked to skills transparency in the hypothesized ways, the lack of good measures of individual skills has prevented previous studies from empirically disentangling the human capital and signaling explanations.

Our goal in this paper is to provide more direct evidence on the relationship between individual-level skills, skills transparency, and the labor market disadvantage of less-educated adults. We use data on 21 countries from the 2011/2012 round of the Programme for the International Assessment of Adult Competencies (PIAAC), which provides high-quality, internationally comparable data on occupational status and, crucially, also on the general literacy and numeracy skills of working-age adults. The data do not allow us to account for occupation-specific skills at the individual level, which are notoriously difficult to measure and which PIAAC did not attempt to assess. For the general skills that were assessed, we can construct direct country-level measures of skills transparency, that is, of how much information an individual's formal educational attainment provides about his/her actual level of skills. More specifically, we consider cross-national differences in the mean skills 
differential between adults with low and intermediate qualifications — the "skills gap" —and in the internal homogeneity of these educational groups. We argue that educational credentials send a stronger signal about an individual's actual skills (i.e., are more "skill-transparent") the larger the skills gap between different educational groups is and the more homogeneous the skills distribution within educational groups is.

Our empirical analysis focuses on differences in occupational status between adults with low (less than upper secondary) and intermediate (upper secondary or post-secondary, nontertiary) levels of formal qualification. We exclude adults with tertiary education because they are unlikely to be direct competitors of the less educated on the labor market. We study differences in occupational status (of the current or last job) because they are less sensitive to differences in overall economic conditions than unemployment rates or wage differentials. This is crucial as the PIAAC data were collected in 2011/12 when several countries in our sample were facing deep recessions. ${ }^{1}$

Applying a two-step regression approach to a final analysis sample of 48,033 less- and intermediate-educated adults in 21 countries, we find support for both the human capital and signaling explanations. As predicted by human capital theory, individuals' actual skills partly explain the lower occupational status of less-educated relative to intermediate-educated adults. Yet being less-educated continues to show a strong negative association with occupational status even after accounting for actual skills at the individual level. Consistent with the signaling story, country-level regressions show that this remaining occupational status gap grows as the aggregate skills gap between less- and intermediate-educated adults increases and as these groups become more homogeneous in terms of actual skills - that is, as skills transparency increases.

\section{THEORETICAL CONSIDERATIONS AND HYPOTHESES}

Human capital theory (Becker 1964) argues that skills enhance productivity and are therefore rewarded by employers. According to this perspective, less-educated adults have the poorest labor market outcomes because of their relative lack of skills (Bills 1990; Solga 2002). Scholars recognize that skills are not homogeneous, but comprise a diverse set of capabilities that differ in their transferability across different types of jobs. For our purposes, the most

\footnotetext{
${ }^{1}$ Another reason why we do not analyze wages is that the PIAAC public use files only provide earnings deciles for several countries. Moreover, cross-national differences in earnings differentials are known to crucially depend on a host of institutional factors (such as collective bargaining arrangements; see Koeniger, Leonardi, and Nunziata 2007). These are difficult to control given the relatively few degrees of freedom at the country level.
} 
important distinction is between general and occupation-specific skills. Whereas general skills such as language and mathematical skills are useful in a wide variety of jobs, occupation-specific skills (e.g., an auto mechanic's understanding of how a car engine works) are, by definition, valuable only in a narrow set of particular occupations. Importantly, the PIAAC data used in our empirical analysis provide high-quality, internationally comparable measures of individuals' general skills, but no direct measures of occupation-specific skills. Only for general skills can we therefore empirically distinguish between a direct individuallevel effect and an aggregate-level effect of the skills distribution of educational groups, a point to which we return below.

According to the human capital perspective, differences in labor market outcomes between less- and intermediate-educated adults reflect differences in skills. We would therefore expect that introducing individual-level general skills into a labor market regression partly accounts for the disadvantaged labor market position of less-educated adults (hypothesis 1). Importantly, the human capital story also suggests a straightforward explanation for crossnational variation in the labor market disadvantage of the less educated: As skills levels of less-educated adults vary across countries (e.g., because of differences in education systems Heisig and Solga 2015; Park and Kyei 2011), accounting for individual-level differences in general skills should reduce cross-national variation in the labor market disadvantage of lesseducated adults (hypothesis 2).

Screening and signaling accounts ${ }^{2}$ suggest that the aggregate skills distributions of less- and intermediate-educated adults might affect the labor market disadvantage of lesseducated workers above and beyond any human capital effects that operate on the individual level. At least in their weak versions (Psacharopoulos 1979; see also Bills, 2003), these accounts do not dispute the crucial assumptions of human capital theory that adults with higher formal qualifications tend to be more productive and that this is rewarded by employers. However, they argue that skills are very difficult to observe and that employers therefore heavily rely on more readily observable proxies for skills and "trainability" in hiring, job placement, and promotion decisions (Spence 1973; Thurow 1979). Educational degrees and other indicators of educational achievement such as grades therefore serve as crucial sources of information (Arrow 1973; Hirsch 1977; Thurow 1979; Weiss 1995). Employers assess the skills of applicants based on beliefs about the skill level of an

\footnotetext{
${ }^{2}$ We treat signaling and screening theories as one general approach in this article. While some scholars view the two as distinct approaches, we concur with Bills' (2003) reading of Weiss (1995) that the two approaches are conceptually very similar and the primary "difference between screening and signaling models is that, in the former, firms move first and, in the latter, students move first” (Bills 2003, 447).
} 
applicant's educational group, that is, they apply statistical discrimination (Aigner and Cain 1977; Phelps 1972).

Employers should be particularly likely "screen" applicants on the basis of educational credentials when the latter are strongly predictive of an individual's actual skills - in other words, when "skills transparency" is high. The signaling mechanism thus suggests that, even after accounting for skills at the individual level, the extent of less-educated adults' labor market disadvantage would still increase with a country's level of skills transparencyreflecting stronger statistical discrimination against all less-educated adults, independent of their individual skills, in more skill-transparent contexts.

Skills transparency, understood as the extent to which formal qualifications are predictive of actual skills, has at least two dimensions (Heisig 2016). The first refers to differences in the average skill levels of different educational groups, that is, to skills gaps between them. The larger skills gaps by level of formal qualification, the more indicative these qualifications are of individuals' actual skills. The second factor is within-group skills homogeneity: Other things being equal — in particular, the skills gap — degrees send a stronger signal when educational groups are internally more homogeneous (Aigner and Cain 1977, 181). Even after controlling for skills at the individual level, we therefore expect the labor market disadvantage of less-educated relative to intermediate-educated adults to increase with the skills gap between the two groups (hypothesis 3) and with their internal homogeneity in terms of skills (hypothesis 4).

As noted above, we can test hypotheses 1 to 4 and disentangle the individual- and aggregate-level effects of skills only with respect to general skills, because PIAAC did not attempt to measure occupation-specific skills (and nor does any other comparative data set that we are aware of). To study (and control for) country differences in the distribution of occupation-specific skills we therefore follow previous research and relate the labor market disadvantage of less-educated adults to the vocational orientation of upper secondary education (e.g., Bol and Van de Werfhorst 2011; Van de Werfhorst 2011). The rationale for assuming a relationship between vocational orientation and the distribution of occupationspecific skills across educational groups is straightforward: In countries with a strong vocational orientation, most adults with an upper secondary degree have completed a program that focuses on occupation-specific skills, with employers usually having a considerable influence on the design of vocational programs. This likely ensures that "more job-relevant skills are acquired that are directly applicable in the workplace" (Van de Werfhorst 2011, 
1080). ${ }^{3}$ Consistent with previous research, we therefore expect the difference in labor market outcomes between less- and intermediate-educated adults to increase with the degree of vocational orientation (hypothesis 5). Unlike in the case of general skills, we cannot empirically separate the individual- and aggregate-level effects of the distribution of occupation-specific skills, however.

\section{RELATION TO PREVIOUS RESEARCH}

By disentangling individual-level "human capital" effects of general skills from aggregatelevel "signaling" or "skills transparency" effects, our study goes beyond previous crossnational research on the labor market disadvantage of less-educated workers and on returns to educational attainment more broadly. Lacking direct measures of skills, many previous studies could examine the effect of skills transparency only indirectly using education system indicators and were unable to control for skills at the individual level (Andersen and Van de Werfhorst 2010; Nelson 2008; Shavit and Müller 1998). Bol and Van de Werfhorst (2011) used self-reported years of schooling as a proxy for skills, but still focused on education systems as the key country-level explanatory variable. A major finding of these studies is that the labor market disadvantage of less-educated adults increases with the extent of external differentiation (i.e., tracking) —often interpreted as a proxy for differences in the transparency of general skills - and with the vocational orientation of (upper) secondary education.

A few previous studies used data from the most ambitious internationally comparative assessment of adult competencies before PIAAC, the mid-1990s International Adult Literacy Survey (IALS). Unfortunately, their findings must be viewed with caution because severe irregularities with the IALS data have emerged in recent years. For the Czech Republic, Germany, Great Britain, and Poland, the distribution of educational degrees differs dramatically from that found in other sources, presumably because of coding errors. Gesthuizen, Solga, and Künster (2011) developed a correction procedure that yields reasonable distributions of educational attainment, but the coding errors likely still contaminate the IALS competence scores, as the latter were imputed on the basis of test performance and background characteristics (presumably including the erroneous education

\footnotetext{
3 A complementary explanation is credentialism - namely that in countries with a stronger vocational orientation in secondary education, occupation-specific credentials are (almost) a necessary prerequisite to enter skilled jobs (e.g., Bills 2003).
} 
measures). ${ }^{4}$ While IALS-based studies could thus seemingly draw on higher-quality individual-level measures of general skills, there are reasons to be concerned about the actual quality of the measures.

Van de Werfhorst's (2011) IALS-based analysis centered on cross-national differences in returns to general skills, after accounting for formal qualifications. Differences between educational groups were not his main focus, but his results do confirm the abovementioned finding that returns to educational degrees are positively related to external differentiation and vocational orientation. In another study based on IALS, Abrassart (2013) found that the labor market disadvantage of less-educated adults (in terms of the employment rate) increases with the aggregate skills gap. While he did not consider the internal homogeneity of the education groups, his study is an important attempt to measure skills transparency more directly. However, Abrassart did not include skills at the individual level, so it remains unclear if, and to what extent, the effect of the aggregate skills gap simply picks up direct, individual-level effect of skills (Farkas and Vicknair 1996). Finally, Gesthuizen, Solga, and Künster (2011) found that, net of individual general competences, the competence mean of the less-educated group is positively related to their average occupational status. They did not consider withingroup homogeneity or the skills gap between the less-educated and intermediate groups.

\section{ALTERNATIVE EXPLANATIONS}

We now discuss alternative explanations for cross-national differences in the labor market disadvantage of less-educated adults and describe how we account for them in the empirical analysis. A first objection to the skills transparency explanation could be that skills gaps between, and the internal homogeneity of, educational groups are difficult to observe for employers. Employers might therefore rely on more readily observable information. One might suspect that it really is the fact of external differentiation itself (rather than its relationship to skills transparency) that shapes employers' beliefs about educational degrees. In a tracked system, employers simply have another piece of information for assessing applicants that their counterparts in undifferentiated systems lack, namely the track (or school type) that someone attended. External differentiation might therefore directly affect the labor market disadvantage of the less educated, rather than via skills transparency. Controlling for a country's degree of external differentiation should then reduce any effects of the direct

\footnotetext{
${ }^{4}$ Unfortunately, documentation for IALS is scarce and we are not aware of any document that provides details on the construction of competence scores. For more information on the procedures used in PIAAC, see OECD (2013).
} 
measures of skills transparency on the labor market disadvantage of less-educated adults (see hypotheses 3 and 4).

A second concern is that our data were collected in 2011/12, when the countries in our sample were characterized by very different labor market conditions. Some countries such as Italy and especially Spain were still in the midst of the deep recessions that unfolded in the years after the 2007 financial crisis. Other countries such as Germany or the United Kingdom were faring much better. Because the labor market prospects of less-educated adults are more strongly tied to the business cycle than those of better-educated workers (Farber 1997), these cross-national differences might confound our results. We account for this possibility in two ways. First, we do not analyze labor market disadvantage in terms of unemployment or nonemployment risks (the outcome studied by Abrassart 2013). Instead, we focus on occupational status in the current or last job, which should be less sensitive to business cycle or economic downturn effects. Information on the last job is available for respondents who worked within the last five years (i.e., at least just before the start of the crisis). Second, we control for differences in labor market conditions using the harmonized unemployment rate in the country-level regressions.

A third potential issue is that the 21 countries included in our analysis differ in the extent of female labor force participation and the proportion of immigrants, which both may contribute to country differences in less-educated adults' labor market disadvantage. It is important to account for female labor force participation because there are systematic differences in occupational status between men and women (see Ganzeboom, de Graaf, and Treiman 1992; Smyth 2005). As for immigrants, extant literature shows that they achieve lower job placement even after accounting for educational attainment (Phalet and Heath 2010). To account for these potential confounders we control for gender, foreign birth, and primary language at the individual level.

Fourth, signaling theory is most persuasive as an account of hiring decisions and especially of hiring decisions concerning workers with little labor market experience (Bills 2003). For more experienced workers, employers can draw on additional information such as individual work history, references, and recommendation to make informed guesses about worker productivity. In making internal promotion decisions (rather than hiring from the outside), employers usually have even more direct information on worker performance. These processes of "employer learning" suggest that the signaling function of educational credentials declines with work experience (Altonji and Pierret 2001). To capture country differences in the age/experience structure of the workforce, we will control for potential 
work experience at the individual level (because potential work experience is very highly correlated with age we do not include the latter as a separate control). We also considered restricting the analysis to adults with limited labor market experience (less than 10 years), but unfortunately case numbers are insufficient for producing meaningful results.

\section{DATA AND METHODS}

\section{Individual-level data and sample}

Our individual-level data are from the first round of PIAAC, conducted in 2011/2012 (OECD 2013). The main analysis uses 21 of the 24 countries that participated in the survey. ${ }^{5}$ Our goal is to explain the labor market disadvantage of less-educated workers (highest degree below the upper secondary level). We therefore exclude respondents with a tertiary degree (levels 5 and 6 according to the 1997 revision of the International Standard Classification of Education; ISCED) from the analysis, as they rarely compete for the same kinds of jobs as less-educated adults. Our sample includes men and women aged 16 to 54 who worked for pay either at the time of interview or within the last five years before the interview. The upper age threshold ensures that results are not affected by cross-country differences in late-career trajectories and the prevalence of early retirement. We exclude respondents who were enrolled in full-time education at the time of interview. To guarantee a good match with the education system measures, we further drop individuals who did not obtain their highest educational degree in the country where they were surveyed.

A total of 48,880 cases meet our sample restrictions. We drop 847 of these cases $(1.7 \%)$ because of missing information on one of the variables included in the analysis. The only variables with non-negligible proportions of missing data are parental education and occupational status, which are unavailable for 3,537 (7.4\%) and 610 (1.3\%) cases, respectively. We use multiple imputation to fill in missing values on these two measures, obtaining imputations separately by country and gender. ${ }^{6}$ We generate ten imputations, one for each of the so-called plausible values for the skills measures (see Section "Individual-level

\footnotetext{
${ }^{5}$ We exclude Cyprus because of a very high share of literacy-related non-respondents (OECD 2013), Russia because of concerns about data quality, and Australia because it does not provide a public-use file.

${ }^{6} \mathrm{We}$ do not impute the other variables because the low proportions of missing data on these measures do not justify the considerable computational effort for obtaining country- and gender-specific imputations.
} 
variables" below). The final sample comprises 48,033 respondents, with country-specific sample sizes ranging from 1,277 cases in Japan to 7,366 cases in Canada.

We use a two-step strategy to test our hypotheses. The first step consists of running a series of country-specific (individual-level) regressions to estimate different variants of the occupational status (ISEI) gap between less- and intermediate-educated adults. In the second step, we then regress the estimated ISEI gaps on the country-level predictors. We provide further details below, after describing the measures used in our analysis.

\section{Individual-level variables}

Our primary dependent variable is occupational status measured as the score on the International Socio-Economic Index of Occupational Status (ISEI; Ganzeboom, De Graaf, and Treiman 1992). We assign scores based on one-digit 2008 International Standard Classification of Occupation (ISCO-08) codes. For respondents who worked at the time of interview ISCO-08 codes refer to the current job. For those who did not work at the time of interview (but stopped working no more than five years ago) codes refer to the respondent's last job.

The one-digit ISCO-08 groups workers into ten broad occupational categories. It would be preferable to assign occupational status using occupational categories at the two- or higherdigit level, but unfortunately four countries in our sample only provide one-digit codes in their PIAAC public use file. To ensure consistency we use the one-digit version of ISCO-08 for all countries in the main analysis. In supplementary analyses, we explored the consequences of using two-digit occupational codes for the 17 countries where these are available and the results were reassuring (see Section "Robustness checks" below).

Our focal individual-level predictor is the respondent's highest educational degree, as our goal is to explain (cross-national differences in) the occupational status (ISEI) gap between less- and intermediate-educated adults. PIAAC provides the highest degree in terms of the 1997 revision of the International Standard Classification of Education (ISCED). We classify respondents as less-educated if their highest degree is at ISCED levels 0-2 and as intermediate-educated if they have attained ISCED levels 3-4. This corresponds to the highest degree being at the lower secondary level or below and at the upper secondary or non-tertiary post-secondary level, respectively.

The unique feature of PIAAC is the availability of direct, high-quality measures of respondents' actual skills. All countries that participated in PIAAC administered test items to assess the reading and text comprehension skills (literacy) and practical mathematical skills 
(numeracy) of participants. To limit respondent burden, each participant received only a relatively small number of test items, rendering individual competence estimates quite uncertain. PIAAC therefore provides ten plausible values rather than a single competence score for each case. To appropriately handle the plausible values (as well as the multiply imputed values for parental education and occupational status), we run all analyses ten times. We then use the appropriate rules for multiply imputed data to obtain final point estimates, standard errors, and p-values (Little and Rubin 2002). ${ }^{7}$

Literacy and numeracy skills are very highly correlated. In our sample, the individual-level Pearson correlation is .85. This usually precludes simultaneous inclusion of both skill domains when there is a substantive interest in their effects. In the present study, however, we have no inherent interest in the effects of skills. We want to know if, and to what extent, they account for (country differences in) the labor market disadvantage of less-educated adults. We therefore measure skills as comprehensively as possible and include both literacy and numeracy skills in the individual-level regressions (see Section "Analytic strategy and estimation" below).

In addition to highest degree and skills, the models include several individual-level control variables: Sex (dummy variable); potential work experience (linear splines with knots at 10, 20, and 30); foreign-birth/foreign-language status (four categories: born in survey country and test language is first language; born in survey country and test language is not first language; born in foreign country and test language is first language; born in foreign country and test language is not first language); parental educational attainment (three categories: no parent has completed upper secondary education; at least one parent has completed upper secondary education; at least one parent has completed tertiary education); respondent was self-employed in last/current job (dummy variable). As our sample includes both currently and formerly employed respondents, one might suggest that we also control for current employment status. However, current employment status likely is strongly endogenous to the outcome variable, as people with lower occupational status have higher risks of unemployment. We therefore do not control for employment status at the individual level. As a robustness check, we repeated the analysis using only respondents who worked at the time of interview. Results were consistent with those presented in the main article (see Section "Robustness Checks" below).

\footnotetext{
${ }^{7}$ In fact, this would have been necessary even in the absence of multiple plausible values because we used multiple imputation to replace missing values on individual-level variables (see above).
} 


\section{Country-level predictors}

A key innovation of our study is to measure skills transparency directly using the skills gap between less- and intermediate educated adults and the internal homogeneity of these groups. In constructing the measures, we closely follow Heisig and Solga's (2015) and especially Heisig's (2016) analyses of the relationship between secondary education systems and skills transparency.

To construct the skills gap measure, we run country-specific regressions with literacy and numeracy skills as the dependent variables and with the sample restrictions matching those of the main analysis. The regressions control for sex, age (five-year groups), and foreignbirth/foreign-language status. We adjust the skills gap for these characteristics because they are readily observable and because we want to isolate the additional information conveyed by an individual's educational degree. The literacy/numeracy gap for a given country simply is the coefficient estimate on having intermediate rather than low formal qualifications in the country-specific regression. Our final measure is the unweighted average of the literacy and numeracy gaps for each country.

To measure the internal homogeneity of the two educational groups, we first compute the residuals from the country-specific regressions used in constructing the skills gap measures. For each educational group and for both literacy and numeracy, we then calculate the standard deviation of the residuals as a straightforward measure of within-group heterogeneity. The resulting four standard deviations (literacy, less educated; numeracy, less educated; literacy intermediate educated; numeracy, intermediate educated) turn out to be strongly positively correlated (Heisig 2016). To reduce the dimensionality, we run a principal factor analysis of the four standard deviations. ${ }^{8}$ The first factor loads positively on all four standard deviations and has an eigenvalue of 2.44 (averaged across the ten plausible values). The internal consistency of is high, with the value of Cronbach's alpha (standardized) being equal to .83 (again, averaging across the ten plausible values). We reverse-code the factor scores to arrive at a measure of within-group homogeneity (i.e., higher values indicate greater homogeneity). We refer to this measure as the index of internal homogeneity.

To examine whether emphasis on occupation-specific skills explains variation in the labor market disadvantage of less-educated adults, we use Bol and van de Werfhorst's (2013) vocational orientation index. This index is based on the proportion of students in uppersecondary education who are enrolled in a vocational program, as provided in two sources:

\footnotetext{
${ }^{8}$ Using the first component from a principal component analysis yields practically identical results (available upon request).
} 
OECD (2006: Table C2.5) and UNESCO's online database (http://data.uis.unesco.org/). Values refer to 2004 (OECD) and 2006 (UNESCO) or the closest year available. Bol and van de Werfhorst constructed this index by running a principal factor analysis. They report an eigenvalue of 1.87 (Bol and van de Werfhorst 2013:295) for the underlying factor. Using the raw data, we calculate Cronbach's alpha as .96 .

To measure the extent of tracking in secondary education, we use the external differentiation index by Bol and van de Werfhorst (2013). The index is based on a principal factor analysis of three measures: age of first selection into different tracks (reverse coded), number of tracks available at age 15, and length of tracked education as a proportion of the total duration of primary and secondary education. Values for these variables refer to 2003 (age of first selection and number of tracks at age 15) and 2002 (length of tracked curriculum) or the closest year available (for details, see Bol and van de Werfhorst 2013). The factor underlying the index has an eigenvalue of 1.76 (Bol and Van de Werfhorst 2013:294). Based on the raw data provided in their data set, we calculate a standardized Cronbach's alpha of .87.

Table 1 provides descriptive statistics for the individual-level variables. Table 2 reports the values of the country-level predictors and Table 3 displays the pairwise correlations between them.

\section{Analytic strategy and estimation}

In the first step of our analysis, we run country-specific regressions of the ISEI score on our focal individual-level predictor, an indicator variable for being less- rather than intermediateeducated, and different sets of additional variables. ${ }^{9}$ The coefficient estimates on the indicator for being less-educated provide our estimates of the country-specific ISEI gaps. We consider three specifications for these individual-level regressions: the first only includes the indicator for being less-educated (unadjusted ISEI gap); the second adds the measures of literacy and numeracy skills to estimate the skills-adjusted ISEI gap; the third specification further includes all individual-level control variables to estimate the fully adjusted ISEI gap.

\footnotetext{
${ }^{9}$ For simplicity, the following discussion pretends that our data contain a single numeracy score and no multiply imputed/plausible values.
} 
Table 1. Individual-level descriptive statistics by country

\begin{tabular}{|c|c|c|c|c|c|c|c|c|c|c|c|c|c|c|c|}
\hline & $\begin{array}{l}\text { Mean } \\
\text { ISEI } \\
\text { score } \\
\end{array}$ & $\begin{array}{c}\% \\
\text { less- } \\
\text { educated } \\
\text { (ISCED } \\
0-2 \text { ) } \\
\end{array}$ & $\begin{array}{c}\% \\
\text { intermediate- } \\
\text { educated } \\
\text { (ISCED } \\
\text { 3/4) } \\
\end{array}$ & $\begin{array}{l}\text { Mean } \\
\text { literacy } \\
\text { score }\end{array}$ & $\begin{array}{c}\text { Mean } \\
\text { numeracy } \\
\text { score }\end{array}$ & $\begin{array}{c}\text { Mean } \\
\text { potential } \\
\text { work } \\
\text { experience } \\
\text { (years) } \\
\end{array}$ & $\begin{array}{c}\% \text { native- } \\
\text { born, test } \\
\text { language is } \\
\text { first } \\
\text { language }\end{array}$ & $\begin{array}{c}\% \text { native- } \\
\text { born, test } \\
\text { language is } \\
\text { not first } \\
\text { language }\end{array}$ & $\begin{array}{l}\% \text { foreign- } \\
\text { born, test } \\
\text { language is } \\
\text { first } \\
\text { language }\end{array}$ & $\begin{array}{c}\% \text { foreign- } \\
\text { born, test } \\
\text { language is } \\
\text { not first } \\
\text { language }\end{array}$ & $\begin{array}{c}\% \\
\text { with low } \\
\text { parental } \\
\text { education } \\
\end{array}$ & $\begin{array}{c}\% \\
\text { with } \\
\text { intermediate } \\
\text { parental } \\
\text { education } \\
\end{array}$ & $\begin{array}{c}\% \\
\text { with high } \\
\text { parental } \\
\text { education }\end{array}$ & $\begin{array}{c}\% \text { self- } \\
\text { employed }\end{array}$ & $\mathrm{N}$ \\
\hline Austria & 40.6 & 17.5 & 82.5 & 270.8 & 276.4 & 21.3 & 92.7 & 2.5 & 1.7 & 3.1 & 26.6 & 59.1 & 14.4 & 10.1 & 2218 \\
\hline Belgium & 36.3 & 18.7 & 81.3 & 264.9 & 270.3 & 21.1 & 90.3 & 2.9 & 2.6 & 4.2 & 46.1 & 39.4 & 14.6 & 11.4 & 1643 \\
\hline Canada & 40.4 & 19.3 & 80.7 & 264.1 & 254.1 & 20.6 & 84.9 & 5.6 & 4.2 & 5.4 & 28.9 & 42.5 & 28.6 & 12.4 & 7366 \\
\hline Czech Rep. & 36.0 & 9.2 & 90.8 & 268.7 & 270.5 & 19.2 & 96.2 & 0.0 & 1.7 & 2.1 & 10.6 & 81.1 & 8.3 & 16.0 & 2385 \\
\hline Denmark & 36.5 & 29.2 & 70.8 & 263.6 & 271.5 & 17.6 & 89.1 & 0.7 & 1.4 & 8.8 & 33.3 & 45.7 & 21.0 & 9.6 & 1847 \\
\hline Estonia & 34.5 & 20.6 & 79.4 & 266.2 & 263.6 & 18.7 & 88.5 & 2.1 & 8.2 & 1.2 & 29.4 & 44.3 & 26.3 & 9.3 & 2479 \\
\hline Finland & 32.6 & 15.0 & 85.0 & 284.5 & 277.2 & 16.2 & 94.1 & 1.6 & 1.4 & 2.9 & 38.0 & 47.1 & 14.9 & 11.6 & 1414 \\
\hline France & 34.4 & 26.0 & 74.0 & 253.9 & 244.9 & 19.3 & 86.1 & 2.2 & 4.9 & 6.7 & 51.4 & 39.4 & 9.1 & 9.2 & 2441 \\
\hline Germany & 35.0 & 14.9 & 85.1 & 261.1 & 262.4 & 21.5 & 83.1 & 2.3 & 3.4 & 11.2 & 13.6 & 60.6 & 25.7 & 7.1 & 2026 \\
\hline Ireland & 34.8 & 31.3 & 68.7 & 258.8 & 247.0 & 18.4 & 79.6 & 0.8 & 10.0 & 9.7 & 60.5 & 27.8 & 11.6 & 14.8 & 1972 \\
\hline Italy & 34.0 & 53.4 & 46.6 & 248.3 & 248.5 & 22.3 & 85.8 & 1.8 & 2.1 & 10.2 & 79.3 & 18.6 & 2.2 & 18.4 & 2127 \\
\hline Japan & 35.2 & 15.2 & 84.8 & 292.4 & 281.3 & 20.1 & 99.4 & 0.1 & 0.3 & 0.2 & 24.9 & 54.2 & 20.9 & 8.7 & 1277 \\
\hline Korea & 32.4 & 19.1 & 80.9 & 260.6 & 250.9 & 22.7 & 97.4 & 0.3 & 1.2 & 1.1 & 65.7 & 26.2 & 8.1 & 23.6 & 1980 \\
\hline Netherlands & 41.9 & 35.9 & 64.1 & 277.7 & 273.9 & 19.1 & 87.8 & 1.0 & 3.1 & 8.0 & 57.9 & 27.0 & 15.1 & 12.0 & 1725 \\
\hline Norway & 36.7 & 32.0 & 68.0 & 270.5 & 269.3 & 16.5 & 84.7 & 1.4 & 0.7 & 13.2 & 28.8 & 45.2 & 26.0 & 8.0 & 1545 \\
\hline Poland & 31.6 & 10.5 & 89.5 & 255.0 & 250.7 & 18.8 & 99.0 & 1.0 & 0.0 & 0.0 & 29.0 & 66.0 & 5.0 & 16.9 & 2969 \\
\hline Slovak Rep. & 36.6 & 11.4 & 88.6 & 272.9 & 275.7 & 19.3 & 92.8 & 5.5 & 0.9 & 0.8 & 26.3 & 67.4 & 6.3 & 15.1 & 2474 \\
\hline Spain & 31.4 & 65.5 & 34.5 & 242.3 & 237.2 & 21.8 & 79.0 & 2.3 & 12.0 & 6.7 & 81.5 & 12.8 & 5.8 & 13.5 & 2247 \\
\hline Sweden & 37.5 & 20.0 & 80.0 & 276.9 & 276.1 & 17.2 & 82.7 & 2.6 & 1.7 & 13.0 & 40.5 & 29.1 & 30.4 & 9.2 & 1470 \\
\hline United Kingdom & 36.0 & 34.8 & 65.2 & 263.9 & 252.5 & 17.2 & 88.9 & 1.6 & 5.2 & 4.4 & 36.1 & 50.4 & 13.4 & 15.8 & 2808 \\
\hline United States & 36.1 & 16.9 & 83.1 & 253.6 & 235.5 & 20.5 & 80.2 & 2.6 & 4.0 & 13.2 & 23.0 & 48.9 & 28.1 & 13.1 & 1620 \\
\hline
\end{tabular}

Note: Values for ISEI score, literacy, numeracy, and parental education are averages across 10 imputations. ISCED=International Standard Classification of Education; ISEI=International Socio-Economic Index of Occupational Status. Low parental education: no parent has completed upper secondary education; intermediate parental education:

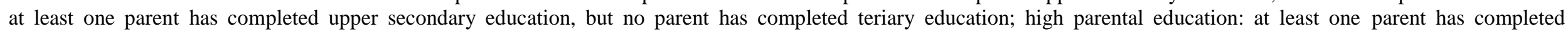
tertiaryeducation.

Sources: PIAAC 2011/2012, authors' calculations. 
Table 2. Descriptives of country-level predictors

\begin{tabular}{|c|c|c|c|c|c|c|}
\hline & $\begin{array}{l}\text { Country } \\
\text { code }\end{array}$ & Skills gap & $\begin{array}{c}\text { Index of } \\
\text { internal } \\
\text { homogeneity }\end{array}$ & $\begin{array}{c}\text { Index of } \\
\text { vocational } \\
\text { orientation }\end{array}$ & $\begin{array}{c}\text { Index of } \\
\text { external } \\
\text { differentiation }\end{array}$ & $\begin{array}{c}\text { Harmonized } \\
\text { unemployment rate } \\
\text { (mean of } 2011 / 12 \\
\text { values) }\end{array}$ \\
\hline & & (1) & $(2)$ & (3) & (4) & $(5)$ \\
\hline Austria & AT & 25.7 & 1.02 & 1.70 & 1.82 & 4.7 \\
\hline Belgium & $\mathrm{BE}$ & 24.4 & 0.16 & 0.94 & 1.02 & 7.4 \\
\hline Canada & $\mathrm{CA}$ & 39.8 & -1.43 & -1.72 & -1.32 & 7.4 \\
\hline Czech Republic & $\mathrm{CZ}$ & 26.4 & 1.34 & 1.74 & 1.62 & 6.8 \\
\hline Denmark & DK & 24.1 & -0.92 & 0.46 & -0.87 & 7.6 \\
\hline Estonia & $\mathrm{EE}$ & 28.5 & 0.24 & -0.44 & Not available & 11.2 \\
\hline Finland & FI & 13.9 & -0.38 & 0.74 & -0.87 & 7.7 \\
\hline France & FR & 27.7 & -0.91 & 0.39 & -0.47 & 9.5 \\
\hline Germany & $\mathrm{DE}$ & 37.5 & -0.86 & 0.89 & 1.86 & 5.6 \\
\hline Ireland & IE & 31.4 & -0.30 & -0.35 & -0.30 & 14.7 \\
\hline Italy & IT & 31.4 & 0.20 & 0.95 & 0.17 & 9.5 \\
\hline Japan & JP & 22.3 & 1.55 & -0.73 & -0.47 & 4.5 \\
\hline Korea & $\mathrm{KR}$ & 25.5 & 1.69 & -0.55 & 0.07 & 3.3 \\
\hline Netherlands & NL & 29.5 & 0.18 & 1.26 & 0.94 & 5.4 \\
\hline Norway & $\mathrm{NO}$ & 17.3 & -0.50 & 0.88 & -1.04 & 3.2 \\
\hline Poland & PL & 20.1 & -0.87 & 0.30 & -0.08 & 9.9 \\
\hline Slovak Republic & SK & 36.9 & 0.78 & 1.49 & 1.62 & 13.8 \\
\hline Spain & ES & 26.6 & 0.70 & -0.00 & -1.02 & 23.1 \\
\hline Sweden & SE & 24.4 & 0.42 & 0.69 & -0.87 & 7.9 \\
\hline United Kingdom & UK & 31.6 & -1.22 & 0.47 & -1.04 & 8.0 \\
\hline United States & US & 35.4 & -0.89 & -1.84 & -1.32 & 8.5 \\
\hline Mean & & 27.4 & 0.13 & 0.51 & 0.21 & 8.1 \\
\hline $\begin{array}{l}\text { Standard } \\
\text { deviation }\end{array}$ & & 6.2 & 0.94 & 1.03 & 1.21 & 4.4 \\
\hline
\end{tabular}

Note: Table reports the values of the predictors as they are provided in the respective sources. For the countrylevel regressions all predictors were (re-)standardized to have a mean of 0 and a standard deviation of 1 within the sample of 21 countries included in this study.

Sources: (1) \& (2): PIAAC 2011/2012, authors' calculations; (3) \& (4) Educational Systems Database, Version 4 (Bol and Van de Werfhorst 2013); (5): OECD Labour Market Statistics, downloaded from https://data.oecd.org/unemp/harmonised-unemployment-rate-hur.htm on July 12, 2016.

Table 3. Pairwise Pearson correlations between country-level predictors

\begin{tabular}{lccccc}
\hline & $(1)$ & $(2)$ & $(3)$ & (4) & (5) \\
\hline (1) Skills gap & 1 & & & & \\
(2) Index of internal homogeneity & -0.230 & 1 & & & \\
(3) Index of vocational orientation & -0.271 & 0.271 & 1 & & \\
(4) Index of external differentiation & 0.196 & $0.442^{+}$ & $0.678^{* *}$ & 1 & -0.172 \\
(5) Harmonized unemployment rate (2011/12) & 0.203 & -0.028 & -0.108 & -0.172 & 1 \\
\hline
\end{tabular}

Note: $\mathrm{N}=21$. For pairwise correlations involving index of external differentiation $\mathrm{N}=20$ because the index is not available for Estonia. $+\mathrm{p}<0.1, * \mathrm{p}<0.05, * * \mathrm{p}<0.01$.

Sources: See Table 2. 
Hypotheses 1 and 2 are assessed on the basis of the first-stage results. With respect to hypothesis 1, we determine if accounting for individual differences in skills (literacy and numeracy) reduces the ISEI gap between less- and intermediate-educated adults. To assess hypothesis 2, we investigate if accounting for these skills differences also reduces crossnational variation in the ISEI gap, that is, if cross-national variation is smaller for the skillsadjusted than for the unadjusted ISEI gap.

In the second step, country-level regressions are used to test hypotheses 3-5. We regress the fully adjusted ISEI gap on different combinations of the country-level predictors. We use the fully adjusted status gap to ensure that the individual-level effects of literacy and numeracy skills and potential confounding factors such as country differences in gender composition are accounted for.

We estimate the first-step country-specific regressions by ordinary least squares, applying PIAAC's final sample weights to account for unequal selection probabilities due to the complex survey design. To estimate the second-step country-level regressions, we use a Feasible Generalized Least Squares (FGLS) approach that accounts for the fact that the dependent variable is estimated rather than observed and therefore subject to sampling error (i.e., we use the coefficient estimates from the first-step regressions and not the unobservable true coefficients). By accounting for country differences in the precision of the first-step estimates, FGLS can achieve greater efficiency than OLS estimation of country-level relationships (for details, see Heisig, Schaeffer, and Giesecke 2015; Lewis and Linzer 2005). A crucial advantage of the two-step approach over other multilevel modeling approaches is that it allows the effects of all individual-level (control) variables to vary freely across countries (Heisig et al. 2015).

\section{RESULTS}

Figure 1 depicts country-specific estimates of the difference in occupational status (as measured by the ISEI score) between adults with low (ISCED categories 0-2) and intermediate (ISCED categories 3-4) formal qualifications. We show three estimates for each country. All three are based on country-specific regressions with occupational status as the dependent and an indicator for having low formal qualifications as the focal independent variable. The estimate of the unadjusted ISEI gap is based on a model without further covariates, the skills-adjusted ISEI gap on regressions that also include literacy and numeracy 
skills, and the fully adjusted ISEI on regressions that add the full set of individual-level controls (sex, potential work experience, foreign-birth/foreign-language status, parental educational attainment, and self-employment).

Figure 1 shows that less-educated adults tend to hold jobs with substantially lower ISEI scores than intermediate-educated adults. The unadjusted ISEI gap is negative and statistically significant in all countries. Yet, its size varies considerably across countries, ranging from 13.0 points in Slovakia to only -3.2 and -3.3 points in Finland and Norway, respectively. The average equals -8.0 points.

Consistent with hypothesis 1 , the skills-adjusted ISEI gap is smaller than the unadjusted gap in all countries. This supports the straightforward human capital argument that the labor market disadvantage of less-educated adults is partly due to a lack of skills. Whereas the average unadjusted ISEI gap for our country sample is approximately -8.0 points, it declines to -5.4 points when we add PIAAC's direct measures of literacy and numeracy skills to the country-specific regressions (skills-adjusted ISEI gap), a reduction of approximately 32 percent.

Figure 1 also shows that country differences in the labor market disadvantage of less-educated adults partly reflect country differences in their level of skills relative to the intermediate group. Accounting for skills at the individual level explains a considerable portion of crossnational variation in the ISEI gap. The cross-country variance is 6.5 for the unadjusted, but only 5.1 for the skills-adjusted ISEI gap, a reduction of approximately 21 percent. This supports hypothesis 2 .

Adding the full set of individual-level controls to the country-specific regressions has inconsistent effects on the estimated ISEI gap. In some cases, the fully adjusted ISEI gap is smaller than the skills-adjusted gap; in other cases, it is larger. The magnitude of the difference is often modest, but there are some countries (e.g., Poland, Slovakia, and the United States) where the additional controls have a substantial impact on the estimated ISEI gap. We report the results of the country-specific regressions with the full set of controls in Appendix A. 
Figure 1. The ISEI gap between less- and intermediate-educated adults in 21 countries

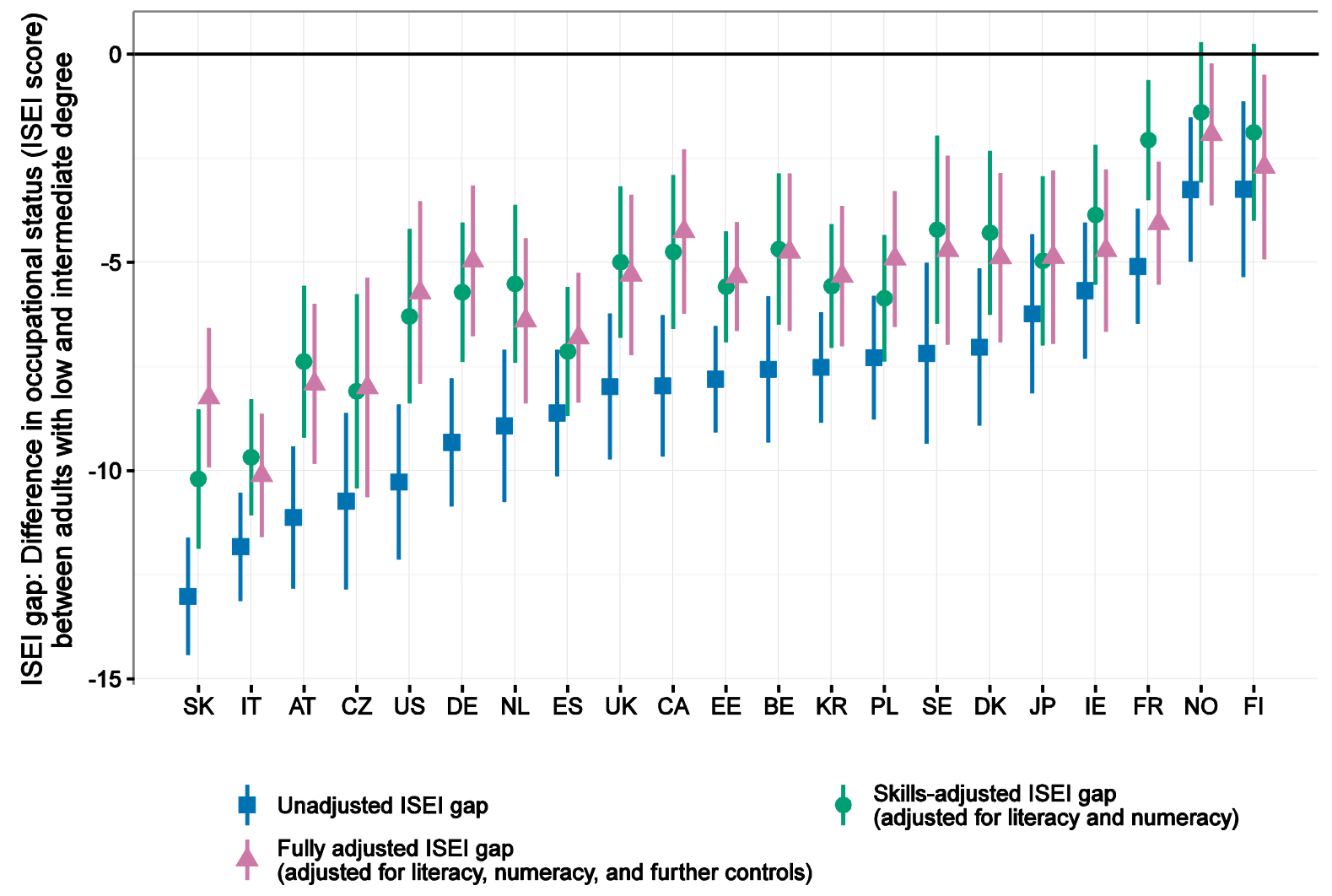

Note: See Table 2 for country codes. ISEI gaps are estimated using country-specific individual-level regressions. Further controls used in estmating the fully adjusted gap: sex, potential work experience, foreign-birth/foreignlanguage status, parental educational attainment, self-employment status.

How can the remaining cross-country variation in the status gap be explained? In Figure 2, we make a first attempt to answer this question by visually exploring the relationships between the fully adjusted ISEI gap (i.e., the triangles in Figure 1) and our focal country-level predictors. The three graphs in Panel I (top row) depict simple bivariate relationships, with the lines representing simple linear fits estimated by OLS. ${ }^{10}$ Consistent with hypotheses 3 to 5 , we find that the labor market disadvantage of less-educated adults tends to increase with the skills gap between less- and intermediate- educated adults, with the internal homogeneity of these groups in terms of general skills, and with the vocational orientation of the education system: The ISEI gap becomes "more negative" as the country-level predictors increase. None of the relationships seems to be driven by single countries, although there are clearly some

${ }^{10}$ The slopes of these lines differ somewhat from those estimated in the formal country-level regression analysis (see Table 4 below) because they are based on the final point estimates (rather than running the countrylevel regressions on each of the ten imputed data set). Moreover, they are based on unweighted regressions, whereas the formal country-level regression analysis uses an FGLS approach that gives greater weight to more precise estimates of the ISEI gap (see Section “Analytic strategy and estimation” above). 
potentially influential cases. Finland and Norway, the two countries where ISEI gap is smallest, both also have very small skills gaps and might therefore have a strong influence on the results. Slovakia, Canada and Italy also look like they might have a strong influence on some of the bivariate relationships in Panel I. We return to potential outlier issues below (see Section "Further analyses and robustness checks").

In Panel II of Figure 2, we examine the partial relationships between the ISEI gap and the country-level predictors. The graphs relate residual variation in the ISEI gap to residual variation in the predictors, after partialling out the effects of the respective other two predictors. For example, we regressed the ISEI gap and the skills gap on the two other predictors (the indices of internal homogeneity and vocational orientation) to compute the residuals depicted in Panel II.A. According to the Frisch-Waugh-Lovell theorem, this has the same effect as controlling for the other two predictors in conventional multiple regression (Davidson and Mackinnon 2004: Chapter 2). The adjusted relationships are generally clearer and stronger than the simple bivariate associations, especially for the skills gap and the index of internal homogeneity. Several countries that look like potential outliers in the bivariate case, no longer appear problematic when the respective other two predictors are taken into account. For example, Canada lies much closer to the regression line in Panel II.A than in Panel I.A: Panel I.A shows that Canada has a relatively small ISEI gap, given its large skills gap between low and intermediate-educated adults. However, this unexpected result is explained very well by the other two predictors, as Canada exhibits very low levels of internal homogeneity and vocational orientation.

Table 4 summarizes the results of the country-level FGLS regressions. We present seven models that cover all possible combinations of the three focal country-level predictors: the skills gap, the index of internal homogeneity, and the index of vocational orientation. Models 1 to 3 include the three predictors one at a time. Models 4 to 6 show the three possible twoway combinations between them and Model 7 includes all three variables simultaneously. All predictors are z-standardized, so the coefficient estimates can be interpreted as the predicted change in the fully adjusted ISEI gap associated with a standard deviation increase in the respective predictor. 
Figure 2. Country-level relationships between ISEI gap and measures of skills transparency

\section{Panel I - Bivariate relationships}
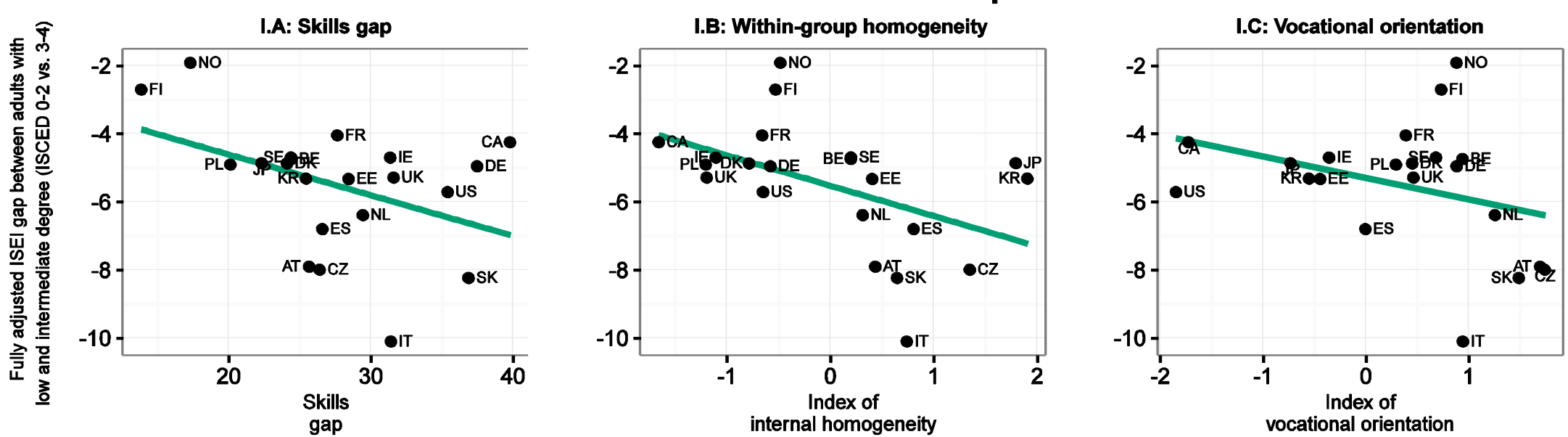

\section{Panel II - Adjusted relationships}
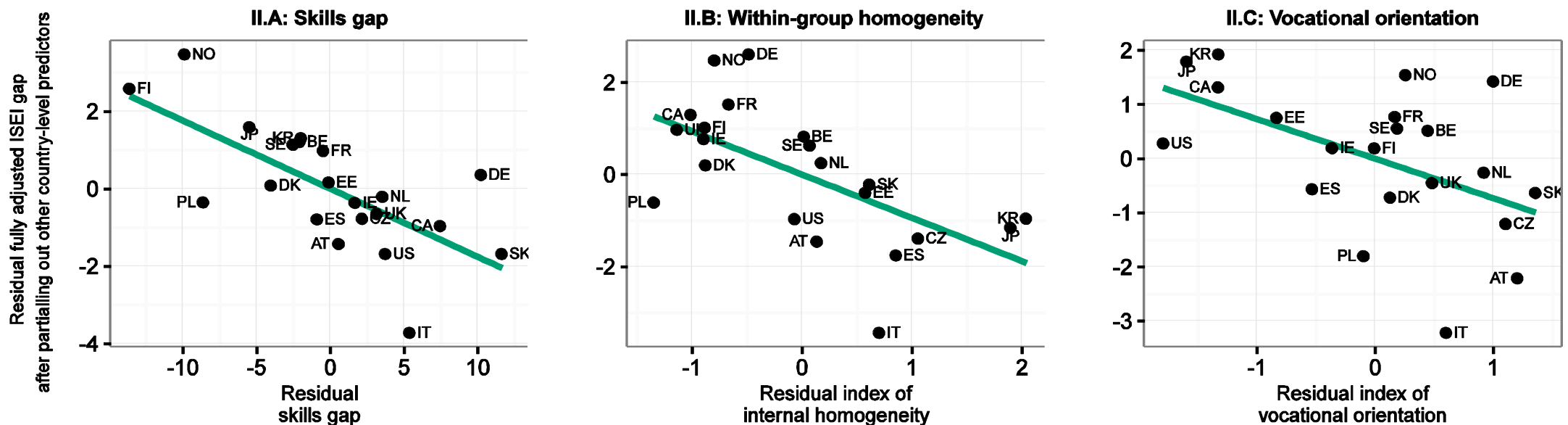

Note: See Table 2 for country codes. Green lines are linear fits estimated using ordinary least squares. Graphs in Panel II show relationships after partialing out the effects of the respective other two predictors. 
The signs of the coefficient estimates in Table 4 are generally consistent with hypotheses 3 to 5 (negative coefficient estimates imply that an increase in the country-level predictor exacerbates the labor market disadvantage of less-educated adults because the intermediate educated are the reference group in the first-step regressions). The skills gap has the clearest and most consistent effect. It is negative and statistically significant at the five percent level or better in all specifications. In Model 1, which includes no other country-level predictors, a standard deviation increase in the skills gap is associated with a -.796 point change in the ISEI gap between less- and intermediate-educated adults. This is a substantial effect, given that the average fully adjusted ISEI gap across the 21 countries in our sample is -5.52 points, with a cross-country standard deviation of 1.88 points. The estimated coefficient of the skills gap is even larger, ranging between -.977 and -1.128 ISEI points per standard deviation increase, when one or both of the other country-level predictors are included in the regression (see Models 4, 5, and 7). Let us stress again that literacy and numeacy skills are included in the country-specific first-step regressions used to estimate the fully adjusted ISEI gap. These results therefore provide strong support for the idea that the size of the aggregate skills differential between less- and intermediate-educated adults has an independent effect on the labor market disadvantage of less-educated adults, as predicted by hypothesis 3 .

Hypothesis 4, which posits a further aggregate-level effect of the internal homogeneity of the educational groups, also receives considerable support. The labor market disadvantage of less-educated adults is larger in countries where the less- and intermediate-educated groups are internally more homogeneous in terms of literacy und numeracy skills and where a person's formal qualificatons therefore send a stronger signal about her actual skills. The effect of the index of internal homogeneity is strongest and most precisely estimated when the skills gap is also included in the regression (Models 4: $b=-1.034, p<.05$; Model 7: $b=-.928$, $\mathrm{p}<.05)$, but even when it is not, the effect of internal homogeneity remains sizable and statistically significant at the five (Model 2: $\mathrm{b}=-.874$ ) or ten percent level (Model 6: $\mathrm{b}=$ .782). These coeffcient estimates are of a similar magnitude as those for the skills gap, again implying substantial cross-national variation of the ISEI gap according to the extent of internal homogeneity. 
Table 4. Country-level regressions of ISEI gap on measures of skills transparency and vocational orientation

\begin{tabular}{|c|c|c|c|c|c|c|c|}
\hline & Model 1 & Model 2 & Model 3 & Model 4 & Model 5 & Model 6 & Model 7 \\
\hline Skills gap & $\begin{array}{l}-0.796+ \\
(0.411)\end{array}$ & & & $\begin{array}{l}-0.977^{*} \\
(0.343)\end{array}$ & $\begin{array}{l}-1.012 * \\
(0.383)\end{array}$ & & $\begin{array}{l}-1.128 * * \\
(0.320)\end{array}$ \\
\hline Index of internal homogeneity & & $\begin{array}{c}-0.874 * \\
(0.396)\end{array}$ & & $\begin{array}{l}-1.034 * * \\
(0.350)\end{array}$ & & $\begin{array}{l}-0.782+ \\
(0.397)\end{array}$ & $\begin{array}{l}-0.928^{*} \\
(0.319)\end{array}$ \\
\hline Index of vocational orientation & & & $\begin{array}{l}-0.641 \\
(0.427)\end{array}$ & & $\begin{array}{l}-0.895^{*} \\
(0.387)\end{array}$ & $\begin{array}{l}-0.482 \\
(0.406)\end{array}$ & $\begin{array}{l}-0.744 * \\
(0.334)\end{array}$ \\
\hline Intercept & $\begin{array}{l}-5.528 * * * \\
(0.396)\end{array}$ & $\begin{array}{l}-5.538 * * * \\
(0.383)\end{array}$ & $\begin{array}{l}-5.537 * * * \\
(0.407)\end{array}$ & $\begin{array}{l}-5.532 * * * \\
(0.334)\end{array}$ & $\begin{array}{l}-5.533 * * * \\
(0.359)\end{array}$ & $\begin{array}{l}-5.540 * * * \\
(0.379)\end{array}$ & $\begin{array}{l}-5.537 * * * \\
(0.306)\end{array}$ \\
\hline$N$ & 21 & 21 & 21 & 21 & 21 & 21 & 21 \\
\hline$R 2$ & 0.17 & 0.21 & 0.11 & 0.46 & 0.37 & 0.27 & 0.59 \\
\hline Adjusted $R 2$ & 0.13 & 0.17 & 0.06 & 0.40 & 0.30 & 0.19 & 0.51 \\
\hline
\end{tabular}

Note: Feasible Generalized Least Squares estimates following Lewis and Linzer (2005), based on 10 imputations/plausible values. The dependent variable is the ISEI gap between less-educated (ISCED categories 0-2) and intermediate-educated (ISCED categories 3/4) adults aged 16-54. The ISEI gap measures the occupational status of less-educated adults compared to intermediate educated adults, so more negative values correspond to a larger disadvantage for the less-educated group. ISEI gap is estimated using country-specific individual-level regressions that control for literacy and numeracy skills, sex, potential work experience, foreignbirth/foreign-language status, parental educational attainment, self-employment status (referred to as the "fully adjusted status gap" in the text). All predictors are $\mathrm{z}$-standardized (mean of 0 , standard deviation of 1). Standard errors in parentheses. $+\mathrm{p}<0.1, * \mathrm{p}<0.05, * * \mathrm{p}<0.01, * * * \mathrm{p}<0.001$ (two-tailed tests).

Sources: PIAAC 2011/2012, authors' calculations.

Finally, our results are also broadly consistent with previous findings that the labor market disdvantage of less-educated adults is larger (or, equivalently, that returns to completing upper secondary education are higher) in countries where upper secondary education puts greater emphasis on occupation-specific skills (e.g., Bol and Van de Werfhorst 2011; Shavit and Müller 1998; Van de Werfhorst 2011). However, a clear effect only emerges when the skills gap is also included in the model (Model 5: $b=-.895 ; \mathrm{p}<.05 ;$ Model 7: $\mathrm{b}=-0.744 ; \mathrm{p}<$ .05). This is because vocational orientation is negatively related to the gap in general (literacy and numeracy) skills between less- and intermediate-educated adults (see Heisig and Solga 2015 and Table 3 above). This negative relationship suppresses the effect of vocational orientation when the skills gap is not held constant. As discussed above (see Section "Theoretical Considerations and Hypotheses"), an obvious interpretation of the aggregate effect of vocational orientation is that it reflects country differences in the occupational skills differential between less- and intermediate-educated adults. Lacking direct measures of occupational skills we cannot, however, investigate this explanation more directly. 


\section{Further analyses and robustness checks}

In Table 5, we present a series of further analyses to assess potential alternative explanations and explore the robustness of our findings. With the first two models, we examine the possibility that the effects of the skills transparency measures are spurious and that external differentiation (i.e., tracking) of students in secondary education is the factor that really drives cross-national differences in the occupational status gap (see Section "Alternative Explanations" above). We cannot include Estonia in this analysis because the index of external differentiation is not available for this country. Model 1 therefore reestimates the final model from Table 4 (Model 7) using the 20 countries for which this information is available. The estimates are very similar to those for the full country sample, although the coefficient on the vocational orientation index now barely fails to reach statistical significance at the five percent level.

Model 2 adds the index of external differentiation. The effects of the skills gap and the index of internal homogeneity actually become slightly stronger in this model and remain statistically significant at the five percent level. The vocational orientation index no longer reaches conventional significance levels in Model $2(p=.13)$. However, this is due to a loss of precision (attributable to the relatively strong positive correlation between vocational orientation and external differentiation; see Table 3 above) rather than to an attenuation of the effect. The magnitude of the point estimate actually increases (in absolute size) compared to Model 1. The external differentiation index itself has a small positive and very imprecisely estimated effect $(b=.258 ; p=.69)$. These results provide no support for the idea that it is the very fact of external differentiation rather than skills transparency that shapes the ISEI gap. However, they are still compatible with the idea that external differentiation affects the ISEI gap indirectly by influencing the level of skills transparency. Model 3 shows that we do indeed find a sizable negative effect of external differentiation $(b=-1.051 ; p=.08)$ on the ISEI gap when the direct measures of skills transparency are not included in the model. This helps to reconcile our results with previous findings that greater external differentiation is associated with greater differentials in labor market outcomes between less- and intermediateeducated adults (e.g., Bol and Van de Werfhorst 2011; Shavit and Müller 1998; Van de Werfhorst 2011). It is also consistent with Heisig and Solga's (2015) and Heisig's (2016) finding that external differentiation is positively related to the skills gap and internal homogeneity (see also Table 3 above). ${ }^{11}$

\footnotetext{
${ }^{11}$ One might argue that the disadvantage of less-educated workers depends on their (absolute) level of skills rather than the (relative) gap between the less- and intermediate-educated groups. Adding the mean skills of the
} 
Table 5. Additional country-level regressions

\begin{tabular}{|c|c|c|c|c|c|}
\hline & $\begin{array}{c}\text { Model } 1 \\
\text { (w/o Estonia) }\end{array}$ & $\begin{array}{c}\text { Model } 2 \\
\text { (w/o Estonia) }\end{array}$ & $\begin{array}{c}\text { Model } 3 \\
\text { (w/oEstonia) }\end{array}$ & Model 4 & Model 5 \\
\hline Skills gap & $\begin{array}{c}-1.129 * * \\
(0.328)\end{array}$ & $\begin{array}{l}-1.247 * \\
(0.434)\end{array}$ & & $\begin{array}{c}-1.043^{* *} \\
(0.315)\end{array}$ & $\begin{array}{l}-0.939 * \\
(0.325)\end{array}$ \\
\hline Index of internal homogeneity & $\begin{array}{c}-0.933^{*} \\
(0.332)\end{array}$ & $\begin{array}{l}-1.005^{*} \\
(0.373)\end{array}$ & & $\begin{array}{c}-0.924 * * \\
(0.307)\end{array}$ & $\begin{array}{c}-1.082 * * \\
(0.335)\end{array}$ \\
\hline Index of vocational orientation & $\begin{array}{c}-0.734+ \\
(0.354)\end{array}$ & $\begin{array}{l}-0.932 \\
(0.579)\end{array}$ & $\begin{array}{c}0.049 \\
(0.564)\end{array}$ & $\begin{array}{c}-0.777^{*} \\
(0.323)\end{array}$ & $\begin{array}{c}-0.727^{*} \\
(0.322)\end{array}$ \\
\hline Index of external differentiation & & $\begin{array}{c}0.275 \\
(0.623)\end{array}$ & $\begin{array}{l}-1.051+ \\
(0.563)\end{array}$ & & \\
\hline Unemployment rate & & & & $\begin{array}{l}-0.422 \\
(0.282)\end{array}$ & $\begin{array}{c}-0.841+ \\
(0.457)\end{array}$ \\
\hline Unemployment rate, squared & & & & & $\begin{array}{c}0.227 \\
(0.198)\end{array}$ \\
\hline Intercept & $\begin{array}{c}-5.545 * * * \\
(0.324)\end{array}$ & $\begin{array}{c}-5.535 * * * \\
(0.334)\end{array}$ & $\begin{array}{c}-5.550 * * * \\
(0.404)\end{array}$ & $\begin{array}{c}-5.515 * * * \\
(0.296)\end{array}$ & $\begin{array}{c}-5.740 * * * \\
(0.354)\end{array}$ \\
\hline$N$ & 20 & 20 & 20 & 21 & 21 \\
\hline$R 2$ & 0.59 & 0.60 & 0.26 & 0.64 & 0.67 \\
\hline Adjusted R2 & 0.51 & 0.49 & 0.17 & 0.55 & 0.56 \\
\hline
\end{tabular}

Note: All predictors except square of unemployment rate are z-standardized (mean of 0, standard deviation of 1). Square of unemployment rate is the square of the $\mathrm{z}$-standardized unemployment rate. Standard errors in parentheses. $+\mathrm{p}<0.1, * \mathrm{p}<0.05$, ** $\mathrm{p}<0.01$, *** $\mathrm{p}<0.001$ (two-tailed tests). See text and note to Table 4 for further information.

Sources: PIAAC 2011/2012, authors' calculations.

Models 4 and 5 adress the concern that the country-level results might be confounded by differences in macroeconomic conditions. Model 4 controls for the harmonized unemployment rate (average of 2011 and 2012 values), Model 5 adds a squared term to allow for a curvilinear effect, which may be important because some countries such as Ireland or Spain were facing exceptionally high levels of unemployment when the PIAAC study was conducted (see Table 2 above). Again, we focus on the robustness of the full model from Table 4 (Model 7), and because we do not include the index of external differentiation we can now use the full country sample including Estonia. As expected, the coefficient estimate of the unemployment rate is negative in Model 4, albeit not statistically significant. More importantly, controlling for the unemployment rate has only small effects on the coefficient estimates on our focal country-level predictors, all of which remain statistically significant at

less-educated to Model 7 in Table 4 does not support this idea, however. The mean skills level of less-educated adults has no significant effect, while the effects of our three focal predictors are robust and remain statistically significant (results available upon request). 
the five percent level or better. This conclusion does not change when we allow for a curvilinear effect of the unemployment rate in Model $5 .^{12}$

We carried out several other robustness checks, which we report in the Appendices B to E. In the first three checks, we reestimated the country-specific fully adjusted ISEI gaps using alternative sample restrictions or measures and then reran the country-level regressions reported in Table 4. We now briefly describe how the resulting coefficient estimates differ from the above results, again focusing on Model 7 in Table 4, which includes the three focal country-level predictors simultaneously.

First, we restricted the sample to respondents who were employed at the time of interview. The coefficient estimates for all three country-level predictors were larger in absolute size than in the main analysis and remained significant at the five percent level or better (see Table B1 in Appendix B).

In a second analysis, we excluded self-employed respondents from the analysis (see Table C1 in Appendix). The coefficient estimates on the skills gap and the index of internal homogeneity both remained statistically significant at the five percent level or better, with the former being slightly larger and the latter slightly smaller (again, in absolute size) than in the main analysis. The effect of the vocational orientation index was noticeably weaker than in the main analysis (-.592 as opposed to -.744 in Table 4 above) and no longer statistically significant $(\mathrm{p}=.13)$.

In a third check, we explored the consequences of assigning ISEI scores on the basis of a more finely grained occupational classification. For the 17 countries that provide two-digit ISCO-08 codes in their public use files (i.e., for all countries except Austria, Canada, Estonia, and Finland), we recalculated the fully adjusted ISEI gap on that basis. The resulting ISEI gaps correlate almost perfectly with the gaps based on one-digit codes $(r=.99$; see Figure D.1 in Appendix D for a visualization). Given this high correlation, the country-level regression results for the 17 country sample are very robust to whether one- or two-digit occupational codes are used (see Tables D.1 and D.2 in Appendix D). That said, the effect of the vocational orientation index is weaker than in the main analysis and no longer statistically significant in the analysis based on two-digit ISCO-08 codes, see Table D.2 in Appendix D). However, it is clear that the difference primarily reflects the change in the underlying country sample rather than the use of more finely grained occupation codes. The effects of the skills gap and the

\footnotetext{
${ }^{12}$ Results for Models 1 to 6 in Table 4 are also robust to the inclusion of the unemployment rate (results available upon request).
} 
index of internal heterogeneity are more robust, remaining significant at the five and ten percent levels, respectively.

In a final series of checks, we investigated potential outlier issues by reestimating Model 7 in Table 4 with one country omitted at a time. The results, summarized in Figure E. 1 in Appendix E, were reassuring. For none of the three focal predictors did we find evidence that a single country case unduly influenced the results, with coefficient estimates generally remaining very similar to those for the full sample. Moreover, the coefficient estimates on the skills gap and the index of internal homogeneity generally remained statistically significant at the five percent level or better. The coefficient estimates on the vocational orientation index remained significant at the ten percent level or better, except when Korea was dropped from the sample $(p=.104)$.

\section{CONCLUSIONS}

The main goal of our paper is to further our understanding of cross-national differences in the labor market disadvantage of less-educated adults. A crucial improvement of our study over previous research is the use of recent, high-quality data on the actual literacy and numeracy skills of adults. Most importantly, we not only use this information to account for skills at the individual level. We also construct direct country-level measures of the signaling value or "skills transparency" of educational degrees: the skills gap between less- and intermediateeducated adults and the internal homogeneity of these groups in terms of skills. Previous studies have generally used external differentiation in (upper) secondary education as a proxy for how much information an educational degree conveys about a person's actual skills.

Our results show that skills are an important predictor of occupational status attainment at the individual level, as predicted by human capital theory. Hence, country differences in the skills of less-educated adults - and in how successfully education systems promote skills development among the less educated - are important sources of country variation in their labor market disadvantage. The effects of skills distributions go beyond the individual level, however. Consistent with theories of labor market signaling and screening, we find strong country-level relationships between the skills transparency of educational degrees and the labor market disadvantage of less-educated adults, even after accounting for skills at the individual level: Their labor market disadvantage grows with the skills differential between less- and intermediate-educated adults and with the internal homogeneity of these groups in terms of literacy und numeracy skills. Consistent with previous research, we also find that a 
stronger vocational orientation of upper secondary education, as measured by a higher proportion of students in vocational programs, is associated with a larger disadvantage of the less-educated group. External differentiation in (upper) secondary education systems does not show a significant effect on labor market disadvantage when the skills gap and internal homogeneity of educational groups are held constant.

Our results are relevant for educational and labor market policy. On the one hand, greater skills transparency of educational degrees may contribute to more performance-based hiring processes. Conversely, low skills transparency may undermine trust in educational degrees. Employers would then presumably pay greater attention to social origin, ethnicity, or gender, raising inequalities by these (ascriptive) characteristics. On the other hand, a potential downside of high levels of skills transparency is that it might induce employers to consider applicants with low qualifications only for the most elementary jobs. Yet, less-educated adults remain a heterogeneous group with substantial intra-group variation in skills even in systems with high skills transparency (Heisig and Solga 2014). High skills transparency might lead to individuals with low formal qualifications being screened out during the early stages of the hiring process. In consequence, the more skilled members of the less-educated group might not easily reach later stages of the hiring process (where they can demonstrate their abilities) and therefore find it difficult to attain "skill-adequate" occupational positions. This suggests that returns to skills may depend on formal qualifications, but the level of skills transparency may moderate this individual-level interaction (i.e., there may be a three-way interaction between skills and educational degrees at the individual and skills transparency at the country level). Future research should investigate this possibility using the direct measures of skills transparency that have proved so useful in the present study. 


\section{REFERENCES}

Abrassart, Aurélien. 2013. "Cognitive Skills Matter: The Employment Disadvantage of LowEducated Workers in Comparative Perspective." European Sociological Review 29(4):707-719.

Aigner, Dennis J. and Glen G. Cain. 1977. "Statistical Theories of Discrimination in Labor Markets." Industrial and Labor Relations Review 30(2):175-187.

Altonji, Joseph G., and Charles R. Pierret. 2001. "Employer Learning and Statistical Discrimination." Quarterly Journal of Economics 116(1):313-350.

Andersen, Robert, and Herman G. Van de Werfhorst. 2010. "Education and Occupational Status in 14 Countries: The Role of Educational Institutions and Labour Market Coordination." British Journal of Sociology 61(2):336-355.

Arrow, Kenneth J. 1973. "Higher Education as a Filter." Journal of Public Economics 2(3):193-216.

Becker, Gary S. 1964. Human Capital: A Theoretical and Empirical Analysis, with Special Reference to Education. New York, NY: Columbia University Press.

Bills, David B. 1990. "Employers' Use of Job History Data for Making Hiring Decisions." Sociological Quarterly 31(1):23-35.

Bills, David B. 2003. "Credentials, Signals, and Screens. Explaining the Relationship between Schooling and Job Assignment." Review of Educational Research 73(4):441-469.

Bol, Thijs, and Herman G. Van de Werfhorst. 2011. "Signals and Closure by Degrees: The Education Effect across 15 European Countries." Research in Social Stratification and Mobility 29:119-132.

Bol, Thijs and Herman G. Van de Werfhorst. 2013. "Educational Systems and the Trade-Off between Labor Market Allocation and Equality of Educational Opportunity." Comparative Education Review 57(2):285-308.

Crouch, Collin, Finegold, David, and Sako, Mari. 1999. Are Skills the Answer? Oxford: Oxford University Press.

Davidson, Russell, and James G. MacKinnon. 2004. Econometric Theory and Methods. Oxford: Oxford University Press.

Farber, Henry. 1997. "The Changing Face of Job Loss in the United States, 1981-1995." Brookings Papers on Economic Activity: Microeconomics. 1997: 55-128.

Farkas, George, and Keven Vicknair. 1996. "Appropriate Tests of Racial Wage Discrimination Require Controls for Cognitive Skill: Comment on Cancio, Evans, and Maume" American Sociological Review 61(4):557-560.

Ganzeboom, Harry B. G., Paul M. de Graaf, and Donald J. Treiman. 1992. A Standard International Socio-economic Index of Occupational Status. Social Science Research 21(1):1-56.

Gesthuizen, Maurice, Heike Solga, and Ralf Künster. 2011. "Context Matters: Economic Marginalisation of Low-Educated Workers in Cross-National Perspective." European Sociological Review 27(2):264-280.

Giddens, Anthony. 2000. The Third Way and its Critics. Cambridge: Polity Press. 
Green, Andy, John Preston, and Jan Germen Janmaat. 2006. Education, Equality and Social Cohesion. Basingstoke: Palgrave Macmillan.

Heisig, Jan Paul. 2016. The signaling value of educational degrees: How can we measure it, how is it related to education systems, and can it account for labor market inequalities? Unpublished manuscript.

Heisig, Jan Paul, Merlin Schaeffer, and Johannes Giesecke. 2015. „Multilevel Modeling When the Effects of Lower-Level Variables Vary Across Clusters. A Monte-Carlo Comparison of Mixed-Effects Models, Cluster-Robust Pooled OLS and Two-Step Estimation." Version: December 14, 2015. Available at SSRN: http://ssrn.com/abstract=2703431.

Heisig, Jan Paul, and Heike Solga. 2014. „Kompetenzen, Arbeitsmarkt- und Weiterbildungschancen von gering Qualifizierten in Deutschland - Befunde aus PIAAC.“ In Kompetenzen von gering Qualifizierten, edited by Projektträger im DLR, pp. 11-31. Bielefeld: W. Bertelsmann Verlag.

Heisig, Jan Paul, and Heike Solga. 2015. "Secondary Education Systems and the General Skills of Less- and Intermediate-educated Adults: A Comparison of 18 Countries." Sociology of Education 88(3):202-225.

Hirsch, Fred. 1977. Social Limits to Growth. Cambridge, MA: Harvard University Press.

Koeniger, Winfried, Marco Leonardi, and Luca Nunziata. 2007. Labor Market Institutions and Wage Inequality. Industrial and Labor Relations Review 60(3):340-356.

Lewis, Jeffrey B., and Drew A. Linzer. 2005. "Estimating Regression Models in Which the Dependent Variable Is Based on Estimates." Political Analysis 13(4):345-64.

Murnane, Richard, John Willett, and Frank Levy. 1995. "The Growing Importance of Cognitive Skills in Wage Determination." Review of Economics and Statistics 77(2):251266.

Little, Roderick J. A., and Donald B. Rubin. 2002. Statistical Analysis with Missing Data. New York: Wiley.

Nelson, Moira. 2008. Education Policy and the Consequences for Labor Market Integration in Denmark, Germany, and the Netherlands. Ph.D. Diss., Department of Political Science, University of North Carolina at Chapel Hill.

OECD. 2006. Education at a Glance. Paris: OECD.

OECD. 2013. Technical Report of the Survey of Adult Skills (PIAAC). Paris: OECD.

Park, Hyunjoon, and Pearl Kyei. 2011. "Literacy Gaps by Educational Attainment: A CrossNational Analysis.” Social Forces 89(3): 879-904.

Phalet, Karen and Anthony Heath. 2010. "From Ethnic Boundaries to Ethnic Penalties." American Behavioral Scientist 53(12): 1824-1850.

Phelps, Edmund S. 1972. "The Statistical Theory of Racism and Sexism." American Economic Review 62(4):659-661.

Psacharopoulos, George. 1979. "On the Weak versus the Strong Version of the Screening Hypothesis." Economics Letters 4(2):181-185.

Shavit, Yossi and Walter Müller (Eds.). 1998. From School to Work. Oxford: Clarendon Press. 
Smyth, Emer. 2005. "Gender Differentiation and Early Labour Market Integration Across Europe." European Societies 7(3):451-479.

Solga, Heike. 2002. "Stigmatization by Negative Selection: Explaining Less-educated People's Decreasing Employment Opportunities." European Sociological Review 18(2):159-178.

Solga, Heike. 2008. "Lack of Training - The Employment Opportunities of Low-Skilled Persons from a Sociological and Micro-Economic Perspective." In Skill Formation Interdisciplinary and Cross-National Perspectives, edited by Mayer, Karl Ulrich, and Heike Solga, pp. 173-204. New York: Cambridge University Press.

Solga, Heike. 2014. "Education, economic inequality, and the promises of the social investment state." Socio-Economic Review 12(2): 269-297.

Spence, Michael. 1973. "Job Market Signaling.” Quarterly Journal of Economics 87(3):355374.

Thurow, Lester C. 1979. “A Job Competition Model.” In Unemployment and Inflation, edited by Michael J. Piore, pp. 17-32. New York: M.E. Sharpe.

Van de Werfhorst, Herman G. 2011. "Skill and Education Effects on Earnings in 18 Countries: The Role of National Educational Institutions." Social Science Research 40(4):1078-1090.

Weiss, Andrew. 1995. "Human Capital vs. Signalling Explanations of Wages." The Journal of Economic Perspectives 9(4):133-154. 


\section{APPENDIX A. COUNTRY-SPECIFIC REGRESSION RESULTS (FIRST-STEP REGRESSIONS)}

Table A.1 shows the detailed results of the country-specific regressions for estimating the fully adjusted ISEI gap, that is, the coefficient estimate on the indicator variable for having low education. The fully adjusted ISEI gap is depicted in Figures 1 and 2 in the main article. It is the dependent variable in the country-level regressions in Tables 4 and 5 in the main article and in the additional analyses reported in Tables B1, C1, and D1 in this online supplement.

Please note that literacy and numeracy scores can range from 0 and 500 on the original scales. For easier interpretation, Table A1 is based on z-standardized scores that have a mean of 0 and a standard deviation of 1 in our analytic sample. 
Table A1. Country-specific regressions of ISEI score on individual-level predictors

\begin{tabular}{|c|c|c|c|c|c|c|c|}
\hline & Austria & Belgium & Canada & $\begin{array}{c}\text { Czech } \\
\text { Republic }\end{array}$ & Denmark & Estonia & Finland \\
\hline \multicolumn{8}{|l|}{$\begin{array}{l}\text { Education (highest } \\
\text { degree) }\end{array}$} \\
\hline Low (ISCED 0-2) & $\begin{array}{c}-7.92 * * * \\
(0.97)\end{array}$ & $\begin{array}{c}-4.75 * * * \\
(0.96)\end{array}$ & $\begin{array}{c}-4.26 * * * \\
(1.00)\end{array}$ & $\begin{array}{c}-8.01 * * * \\
(1.34)\end{array}$ & $\begin{array}{c}-4.88 * * * \\
(1.03)\end{array}$ & $\begin{array}{c}-6.81 * * * \\
(0.79)\end{array}$ & $\begin{array}{l}-2.71 * \\
(1.13)\end{array}$ \\
\hline \multicolumn{8}{|l|}{ Skills } \\
\hline Literacy & $\begin{array}{c}3.93 * * * \\
(0.90)\end{array}$ & $\begin{array}{l}2.18^{*} \\
(1.06)\end{array}$ & $\begin{array}{l}2.73 * * \\
(0.97)\end{array}$ & $\begin{array}{c}1.26 \\
(1.00)\end{array}$ & $\begin{array}{l}3.08 * * \\
(0.94)\end{array}$ & $\begin{array}{l}-0.02 \\
(0.67)\end{array}$ & $\begin{array}{c}1.16 \\
(0.85)\end{array}$ \\
\hline Numeracy & $\begin{array}{l}1.91^{*} \\
(0.90)\end{array}$ & $\begin{array}{l}2.15+ \\
(1.14)\end{array}$ & $\begin{array}{c}0.92 \\
(1.02)\end{array}$ & $\begin{array}{l}2.59^{*} \\
(1.13)\end{array}$ & $\begin{array}{l}1.34 \\
(0.97)\end{array}$ & $\begin{array}{l}2.28^{* *} \\
(0.71)\end{array}$ & $\begin{array}{l}2.37 * * \\
(0.89)\end{array}$ \\
\hline \multicolumn{8}{|l|}{ Gender } \\
\hline Female & Ref. & Ref. & Ref. & Ref. & Ref. & Ref. & Ref. \\
\hline Male & $\begin{array}{l}-1.50^{*} \\
(0.71)\end{array}$ & $\begin{array}{c}0.93 \\
(0.82)\end{array}$ & $\begin{array}{c}-6.11 * * * \\
(0.77)\end{array}$ & $\begin{array}{c}-3.82 * * * \\
(0.95)\end{array}$ & $\begin{array}{c}-3.16^{* * * *} \\
(0.86)\end{array}$ & $\begin{array}{l}-0.92 \\
(0.65)\end{array}$ & $\begin{array}{l}-0.14 \\
(0.80)\end{array}$ \\
\hline $\begin{array}{l}\text { Foreign-birth/foreign- } \\
\text { language status } \\
\text { Native-born, test language } \\
\text { is first language }\end{array}$ & Ref. & Ref. & Ref. & Ref. & Ref. & Ref. & Ref. \\
\hline $\begin{array}{l}\text { Native-born, test language } \\
\text { is not first language } \\
\text { Foreign-born, test } \\
\text { language is first language }\end{array}$ & $\begin{array}{l}2.22 \\
(2.16) \\
7.88 * * \\
(2.98)\end{array}$ & $\begin{array}{l}5.21 * \\
(2.05) \\
-1.64 \\
(2.37)\end{array}$ & $\begin{array}{c}3.91 * * \\
(1.29) \\
2.13 \\
(2.23)\end{array}$ & $\begin{array}{c}9.38 \\
(16.57) \\
4.02 \\
(4.07)\end{array}$ & $\begin{array}{l}14.67 * \\
(7.23) \\
-1.31 \\
(2.50)\end{array}$ & $\begin{array}{c}1.49 \\
(2.27) \\
-1.99+ \\
(1.16)\end{array}$ & $\begin{array}{l}5.18+ \\
(2.83) \\
-0.22 \\
(2.76)\end{array}$ \\
\hline $\begin{array}{l}\text { Foreign-born, test } \\
\text { language is not first } \\
\text { language }\end{array}$ & $\begin{array}{l}-1.50 \\
(1.98)\end{array}$ & $\begin{array}{l}2.45 \\
(2.11)\end{array}$ & $\begin{array}{c}1.28 \\
(1.77)\end{array}$ & $\begin{array}{l}-2.66 \\
(3.72)\end{array}$ & $\begin{array}{l}-1.44 \\
(1.02)\end{array}$ & $\begin{array}{c}-3.42 * * \\
(1.18)\end{array}$ & $\begin{array}{l}-1.50 \\
(2.30)\end{array}$ \\
\hline $\begin{array}{l}\text { Parental education } \\
\text { Neither parent completed } \\
\text { upper secondary education }\end{array}$ & Ref. & Ref. & Ref. & Ref. & Ref. & Ref. & Ref. \\
\hline $\begin{array}{l}\text { At least one parent } \\
\text { completed upper } \\
\text { secondary education }\end{array}$ & $\begin{array}{c}3.47 * * * \\
(0.90)\end{array}$ & $\begin{array}{c}3.16 * * * \\
(0.92)\end{array}$ & $\begin{array}{l}2.02 * \\
(0.93)\end{array}$ & $\begin{array}{l}3.77 * \\
(1.46)\end{array}$ & $\begin{array}{c}0.84 \\
(0.96)\end{array}$ & $\begin{array}{l}3.54 * * \\
(1.19)\end{array}$ & $\begin{array}{c}1.20 \\
(0.88)\end{array}$ \\
\hline $\begin{array}{l}\text { At least one parent } \\
\text { completed tertiary } \\
\text { education }\end{array}$ & $\begin{array}{c}5.84 * * * \\
(1.25)\end{array}$ & $\begin{array}{c}8.27 * * * \\
(1.42)\end{array}$ & $\begin{array}{l}2.90 * \\
(1.13)\end{array}$ & $\begin{array}{l}7.08 * * * \\
(2.10)\end{array}$ & $\begin{array}{l}2.18+ \\
(1.27)\end{array}$ & $\begin{array}{l}3.16+ \\
(1.65)\end{array}$ & $\begin{array}{l}3.74 * * \\
(1.33)\end{array}$ \\
\hline \multicolumn{8}{|l|}{$\begin{array}{l}\text { Potential work } \\
\text { experience } \\
\text { (Linear splines) }\end{array}$} \\
\hline $0-10$ & $\begin{array}{c}0.13 \\
(0.21)\end{array}$ & $\begin{array}{c}0.04 \\
(0.21)\end{array}$ & $\begin{array}{c}0.82 * * * \\
(0.19)\end{array}$ & $\begin{array}{l}0.64 * * \\
(0.22)\end{array}$ & $\begin{array}{l}0.33+ \\
(0.17)\end{array}$ & $\begin{array}{l}-0.08 \\
(0.20)\end{array}$ & $\begin{array}{l}0.27+ \\
(0.15)\end{array}$ \\
\hline $10-20$ & $\begin{array}{c}0.22 \\
(0.15)\end{array}$ & $\begin{array}{l}0.48 * * \\
(0.17)\end{array}$ & $\begin{array}{l}0.37 * \\
(0.16)\end{array}$ & $\begin{array}{l}-0.41 * \\
(0.18)\end{array}$ & $\begin{array}{l}0.41^{*} \\
(0.18)\end{array}$ & $\begin{array}{c}0.09 \\
(0.14)\end{array}$ & $\begin{array}{c}0.16 \\
(0.17)\end{array}$ \\
\hline $20-30$ & $\begin{array}{l}-0.04 \\
(0.14)\end{array}$ & $\begin{array}{c}0.05 \\
(0.16)\end{array}$ & $\begin{array}{c}0.04 \\
(0.15)\end{array}$ & $\begin{array}{c}0.24 \\
(0.20)\end{array}$ & $\begin{array}{l}0.35+ \\
(0.19)\end{array}$ & $\begin{array}{c}0.00 \\
(0.13)\end{array}$ & $\begin{array}{l}0.37^{*} \\
(0.18)\end{array}$ \\
\hline $30+$ & $\begin{array}{l}0.43 * \\
(0.22)\end{array}$ & $\begin{array}{c}0.05 \\
(0.22)\end{array}$ & $\begin{array}{l}-0.10 \\
(0.21)\end{array}$ & $\begin{array}{l}-0.10 \\
(0.36)\end{array}$ & $\begin{array}{l}-0.55 \\
(0.34)\end{array}$ & $\begin{array}{l}-0.04 \\
(0.14)\end{array}$ & $\begin{array}{l}-0.54+ \\
(0.28)\end{array}$ \\
\hline $\begin{array}{l}\text { Self-employed } \\
\text { No }\end{array}$ & Ref. & Ref. & Ref. & Ref. & Ref. & Ref. & Ref. \\
\hline Yes & $\begin{array}{c}0.61 \\
(1.46)\end{array}$ & $\begin{array}{l}3.73 * \\
(1.47)\end{array}$ & $\begin{array}{c}4.08 * * * \\
(1.22)\end{array}$ & $\begin{array}{l}3.93 * * \\
(1.45)\end{array}$ & $\begin{array}{l}-2.76+ \\
(1.44)\end{array}$ & $\begin{array}{c}5.79 * * * \\
(1.15)\end{array}$ & $\begin{array}{l}-0.62 \\
(1.30)\end{array}$ \\
\hline Constant & $\begin{array}{l}35.25 * * * \\
(1.85)\end{array}$ & $\begin{array}{l}29.04 * * * \\
(1.75)\end{array}$ & $\begin{array}{l}32.27 * * * \\
(1.58)\end{array}$ & $\begin{array}{l}29.92 * * * \\
(2.13)\end{array}$ & $\begin{array}{l}32.97 * * * \\
(1.40)\end{array}$ & $\begin{array}{l}36.52 * * * \\
(1.76)\end{array}$ & $\begin{array}{l}26.98 * * * \\
(1.21)\end{array}$ \\
\hline $\mathrm{N}$ & 2218 & 1643 & 7366 & 2385 & 1847 & 2247 & 1414 \\
\hline $\mathrm{R} 2$ & 0.16 & 0.14 & 0.14 & 0.12 & 0.14 & 0.14 & 0.09 \\
\hline
\end{tabular}

Notes: Multiple imputation estimates (10 imputations/plausible values). Survey weights applied. Standard errors in parentheses. Literacy and numeracy skills are z-standardized. $+p<0.10, * p<0.05, * * p<0.01$.

ISEI = International Socio-Economic Index of Occupational Status. ISCED = International Standard Classification of Education. Ref. = Reference category.

Source: PIAAC 2011/12, authors' calculations.

Table continues on next page (countries in alphabetic order). 
Table A1. Country-specific regressions of ISEI score on individual-level predictors

\begin{tabular}{|c|c|c|c|c|c|c|c|}
\hline & France & Germany & Ireland & Italy & Japan & Korea & Netherlands \\
\hline \multicolumn{8}{|l|}{$\begin{array}{l}\text { Education (highest } \\
\text { degree) }\end{array}$} \\
\hline Low (ISCED 0-2) & $\begin{array}{c}-4.06 * * * \\
(0.75)\end{array}$ & $\begin{array}{c}-4.96 * * * \\
(0.92)\end{array}$ & $\begin{array}{c}-4.71 * * * \\
(0.99)\end{array}$ & $\begin{array}{c}-10.11 * * * \\
(0.75)\end{array}$ & $\begin{array}{c}-4.88 * * * \\
(1.06)\end{array}$ & $\begin{array}{c}-5.33 * * * \\
(0.86)\end{array}$ & $\begin{array}{c}-6.40 * * * \\
(1.01)\end{array}$ \\
\hline \multicolumn{8}{|l|}{ Skills } \\
\hline Literacy & $\begin{array}{l}-0.67 \\
(0.64)\end{array}$ & $\begin{array}{c}2.81 * * * \\
(0.72)\end{array}$ & $\begin{array}{c}1.32 \\
(1.08)\end{array}$ & $\begin{array}{c}0.40 \\
(0.72)\end{array}$ & $\begin{array}{c}0.35 \\
(1.49)\end{array}$ & $\begin{array}{c}1.44 \\
(1.07)\end{array}$ & $\begin{array}{l}2.94 * * \\
(1.03)\end{array}$ \\
\hline Numeracy & $\begin{array}{c}4.49 * * * \\
(0.63)\end{array}$ & $\begin{array}{c}0.86 \\
(0.75)\end{array}$ & $\begin{array}{c}1.47 \\
(1.03)\end{array}$ & $\begin{array}{l}1.77^{*} \\
(0.71)\end{array}$ & $\begin{array}{c}1.78 \\
(1.42)\end{array}$ & $\begin{array}{c}1.09 \\
(1.03)\end{array}$ & $\begin{array}{c}1.42 \\
(1.10)\end{array}$ \\
\hline \multicolumn{8}{|l|}{ Gender } \\
\hline Female & Ref. & Ref. & Ref. & Ref. & Ref. & Ref. & Ref. \\
\hline Male & $\begin{array}{c}2.17 * * * \\
(0.61)\end{array}$ & $\begin{array}{c}-2.92 * * * \\
(0.67)\end{array}$ & $\begin{array}{c}-2.89 * * * \\
(0.82)\end{array}$ & $\begin{array}{l}-0.17 \\
(0.65)\end{array}$ & $\begin{array}{l}-0.61 \\
(0.84)\end{array}$ & $\begin{array}{l}-1.02 \\
(0.64)\end{array}$ & $\begin{array}{l}-0.32 \\
(0.88)\end{array}$ \\
\hline \multicolumn{8}{|l|}{$\begin{array}{l}\text { Foreign-birth/foreign- } \\
\text { language status }\end{array}$} \\
\hline $\begin{array}{l}\text { Native-born, test language } \\
\text { is not first language } \\
\text { Foreign-born, test } \\
\text { language is first language }\end{array}$ & $\begin{array}{c}0.92 \\
(1.90) \\
-1.63 \\
(1.37)\end{array}$ & $\begin{array}{l}0.57 \\
(2.31) \\
-1.18 \\
(1.35)\end{array}$ & $\begin{array}{l}-1.68 \\
(4.32) \\
-1.69 \\
(1.39)\end{array}$ & $\begin{array}{c}-3.35+ \\
(1.88) \\
0.33 \\
(2.36)\end{array}$ & $\begin{array}{c}-9.16 * * * \\
(1.36) \\
4.75 \\
(5.47)\end{array}$ & $\begin{array}{c}0.30 \\
(4.76) \\
2.62 \\
(2.89)\end{array}$ & $\begin{array}{l}5.05 \\
(5.18) \\
-1.71 \\
(3.19)\end{array}$ \\
\hline $\begin{array}{l}\text { Foreign-born, test } \\
\text { language is not first } \\
\text { language }\end{array}$ & $\begin{array}{c}1.60 \\
(1.20)\end{array}$ & $\begin{array}{l}-1.31 \\
(1.12)\end{array}$ & $\begin{array}{l}-3.08^{*} \\
(1.52)\end{array}$ & $\begin{array}{c}-5.80 * * * \\
(0.88)\end{array}$ & $\begin{array}{l}-12.98 * * * \\
(3.77)\end{array}$ & $\begin{array}{c}0.31 \\
(4.18)\end{array}$ & $\begin{array}{l}-2.16 \\
(1.90)\end{array}$ \\
\hline $\begin{array}{l}\text { Parental education } \\
\text { Neither parent completed } \\
\text { upper secondary education }\end{array}$ & Ref. & Ref. & Ref. & Ref. & Ref. & Ref. & Ref. \\
\hline $\begin{array}{l}\text { At least one parent } \\
\text { completed upper } \\
\text { secondary education }\end{array}$ & $\begin{array}{l}1.60 * \\
(0.80)\end{array}$ & $\begin{array}{l}1.66 \\
(1.19)\end{array}$ & $\begin{array}{c}0.93 \\
(0.94)\end{array}$ & $\begin{array}{c}3.39 * * * \\
(0.94)\end{array}$ & $\begin{array}{c}0.58 \\
(1.08)\end{array}$ & $\begin{array}{c}1.16 \\
(0.84)\end{array}$ & $\begin{array}{c}0.36 \\
(1.06)\end{array}$ \\
\hline $\begin{array}{l}\text { At least one parent } \\
\text { completed tertiary } \\
\text { education }\end{array}$ & $\begin{array}{l}3.57 * * \\
(1.30)\end{array}$ & $\begin{array}{l}3.66 * * \\
(1.33)\end{array}$ & $\begin{array}{c}1.55 \\
(1.53)\end{array}$ & $\begin{array}{l}8.27 * \\
(3.30)\end{array}$ & $\begin{array}{l}3.42 * \\
(1.41)\end{array}$ & $\begin{array}{c}7.03 * * * \\
(1.59)\end{array}$ & $\begin{array}{l}2.76^{*} \\
(1.36)\end{array}$ \\
\hline \multicolumn{8}{|l|}{$\begin{array}{l}\text { Potential work } \\
\text { experience } \\
\text { (Linear splines) }\end{array}$} \\
\hline $0-10$ & $\begin{array}{l}0.34^{*} \\
(0.15)\end{array}$ & $\begin{array}{l}0.67 * * \\
(0.22)\end{array}$ & $\begin{array}{c}0.21 \\
(0.18)\end{array}$ & $\begin{array}{c}0.35 \\
(0.22)\end{array}$ & $\begin{array}{c}0.31 \\
(0.22)\end{array}$ & $\begin{array}{c}0.88 * * * \\
(0.22)\end{array}$ & $\begin{array}{l}0.66^{* *} \\
(0.21)\end{array}$ \\
\hline $10-20$ & $\begin{array}{l}0.36^{* *} \\
(0.13)\end{array}$ & $\begin{array}{l}-0.29+ \\
(0.15)\end{array}$ & $\begin{array}{c}0.17 \\
(0.16)\end{array}$ & $\begin{array}{l}0.30^{*} \\
(0.13)\end{array}$ & $\begin{array}{l}0.39^{*} \\
(0.15)\end{array}$ & $\begin{array}{l}-0.35^{*} \\
(0.16)\end{array}$ & $\begin{array}{c}0.18 \\
(0.18)\end{array}$ \\
\hline $20-30$ & $\begin{array}{c}0.19 \\
(0.12)\end{array}$ & $\begin{array}{c}0.09 \\
(0.14)\end{array}$ & $\begin{array}{c}0.09 \\
(0.17)\end{array}$ & $\begin{array}{c}0.17 \\
(0.12)\end{array}$ & $\begin{array}{c}0.23 \\
(0.17)\end{array}$ & $\begin{array}{l}-0.07 \\
(0.12)\end{array}$ & $\begin{array}{l}-0.25 \\
(0.18)\end{array}$ \\
\hline $30+$ & $\begin{array}{c}0.24 \\
(0.19)\end{array}$ & $\begin{array}{c}0.09 \\
(0.22)\end{array}$ & $\begin{array}{c}0.00 \\
(0.25)\end{array}$ & $\begin{array}{l}-0.20 \\
(0.16)\end{array}$ & $\begin{array}{c}-0.44 \\
(0.32)\end{array}$ & $\begin{array}{c}0.20 \\
(0.15)\end{array}$ & $\begin{array}{l}0.49+ \\
(0.30)\end{array}$ \\
\hline Self-employed & & & & & & & \\
\hline $\begin{array}{l}\text { No } \\
\text { Yes }\end{array}$ & $\begin{array}{l}\text { Ref. } \\
-7.30 * * * \\
(1.04)\end{array}$ & $\begin{array}{l}\text { Ref. } \\
2.35 \\
(1.49)\end{array}$ & $\begin{array}{l}\text { Ref. } \\
-1.95 \\
(1.23)\end{array}$ & $\begin{array}{l}\text { Ref. } \\
2.83^{* *} \\
(0.90)\end{array}$ & $\begin{array}{l}\text { Ref. } \\
1.01 \\
(1.84)\end{array}$ & $\begin{array}{l}\text { Ref. } \\
2.61^{* *} \\
(0.84)\end{array}$ & $\begin{array}{l}\text { Ref. } \\
6.32 * * * \\
(1.61)\end{array}$ \\
\hline Constant & $\begin{array}{l}29.00 * * * \\
(1.27)\end{array}$ & $\begin{array}{l}30.75 * * * \\
(1.92)\end{array}$ & $\begin{array}{l}35.70 * * * \\
(1.30)\end{array}$ & $\begin{array}{l}33.27 * * * \\
(1.90)\end{array}$ & $\begin{array}{l}28.22 * * * \\
(2.06)\end{array}$ & $\begin{array}{l}27.23 * * * \\
(1.74)\end{array}$ & $\begin{array}{l}35.49 * * * \\
(1.54)\end{array}$ \\
\hline $\mathrm{N}$ & 2441 & 2026 & 1972 & 2127 & 1277 & 1980 & 1725 \\
\hline $\mathrm{R} 2$ & 0.13 & 0.14 & 0.08 & 0.23 & 0.08 & 0.10 & 0.14 \\
\hline
\end{tabular}

Notes: Multiple imputation estimates (10 imputations/plausible values). Survey weights applied. Standard errors in parentheses. Literacy and numeracy skills are z-standardized. $+\mathrm{p}<0.10, * \mathrm{p}<0.05, * * \mathrm{p}<0.01$.

ISEI = International Socio-Economic Index of Occupational Status. ISCED = International Standard Classification of Education. Ref. = Reference category.

Source: PIAAC 2011/12, authors' calculations.

Table continues on next page (countries in alphabetic order). 
Table A1. Country-specific regressions of ISEI score on individual-level predictors

\begin{tabular}{|c|c|c|c|c|c|c|c|}
\hline & Norway & Poland & $\begin{array}{c}\text { Slovak } \\
\text { Republic }\end{array}$ & Spain & Sweden & $\begin{array}{c}\text { United } \\
\text { Kingdom }\end{array}$ & $\begin{array}{l}\text { United } \\
\text { States }\end{array}$ \\
\hline \multicolumn{8}{|l|}{$\begin{array}{l}\text { Education (highest } \\
\text { degree) }\end{array}$} \\
\hline Low (ISCED 0-2) & $\begin{array}{l}-1.93 * \\
(0.87)\end{array}$ & $(0.83)$ & $\begin{array}{c}-8.25 * * * \\
(0.85)\end{array}$ & $\begin{array}{c}-6.81 * * * \\
(0.79)\end{array}$ & $\begin{array}{c}-4.71 * * * \\
(1.15)\end{array}$ & $\begin{array}{c}-5.30 * * * \\
(0.98)\end{array}$ & $\begin{array}{c}-5.72 * * * \\
(1.12)\end{array}$ \\
\hline $\begin{array}{l}\text { Intermediate (ISCED 3/4) } \\
\text { Skills }\end{array}$ & Ref. & Ref. $-4.92 * * *$ & Ref. & Ref. & Ref. & Ref. & Ref. \\
\hline Literacy & $\begin{array}{c}3.57 * * * \\
(0.88)\end{array}$ & $\begin{array}{l}1.56^{*} \\
(0.75)\end{array}$ & $\begin{array}{l}-0.34 \\
(0.91)\end{array}$ & $\begin{array}{l}-0.02 \\
(0.67)\end{array}$ & $\begin{array}{l}2.61+ \\
(1.44)\end{array}$ & $\begin{array}{c}1.85 \\
(1.21)\end{array}$ & $\begin{array}{l}2.47+ \\
(1.24)\end{array}$ \\
\hline Numeracy & $\begin{array}{c}0.24 \\
(0.89)\end{array}$ & $\begin{array}{l}1.39+ \\
(0.77)\end{array}$ & $\begin{array}{l}2.77 * * \\
(1.03)\end{array}$ & $\begin{array}{l}2.28^{* *} \\
(0.71)\end{array}$ & $\begin{array}{l}1.46 \\
(1.44)\end{array}$ & $\begin{array}{l}2.09+ \\
(1.23)\end{array}$ & $\begin{array}{c}1.39 \\
(1.21)\end{array}$ \\
\hline \multicolumn{8}{|l|}{ Gender } \\
\hline Female & Ref. & Ref. & Ref. & Ref. & Ref. & Ref. & Ref. \\
\hline Male & $\begin{array}{l}2.03^{*} \\
(0.82)\end{array}$ & $\begin{array}{c}-1.97 * * \\
(0.74)\end{array}$ & $\begin{array}{c}-3.44 * * * \\
(0.72)\end{array}$ & $\begin{array}{l}-0.92 \\
(0.65)\end{array}$ & $\begin{array}{c}0.12 \\
(0.95)\end{array}$ & $\begin{array}{c}-3.50 * * * \\
(0.91)\end{array}$ & $\begin{array}{c}-2.80^{* *} \\
(0.90)\end{array}$ \\
\hline \multicolumn{8}{|l|}{$\begin{array}{l}\text { Foreign-birth/foreign- } \\
\text { language status }\end{array}$} \\
\hline $\begin{array}{l}\text { Native-born, test language } \\
\text { is not first language } \\
\text { Foreign-born, test } \\
\text { language is first language }\end{array}$ & $\begin{array}{c}-2.87 \\
(2.72) \\
7.41 \\
(5.76)\end{array}$ & $\begin{array}{c}-0.73 \\
(1.87) \\
3.42 \\
(2.06)\end{array}$ & $\begin{array}{c}0.45 \\
(1.24) \\
0.17 \\
(2.73)\end{array}$ & $\begin{array}{c}1.49 \\
(2.27) \\
-1.99+ \\
(1.16)\end{array}$ & $\begin{array}{l}1.50 \\
(2.89) \\
-3.97 \\
(3.10)\end{array}$ & $\begin{array}{l}9.83 * * \\
(3.77) \\
5.19 * \\
(2.30)\end{array}$ & $\begin{array}{c}2.06 \\
(2.53) \\
1.13 \\
(2.34)\end{array}$ \\
\hline $\begin{array}{l}\text { Foreign-born, test } \\
\text { language is not first } \\
\text { language }\end{array}$ & $\begin{array}{c}-3.19 * * \\
(1.17)\end{array}$ & & $\begin{array}{c}2.70 \\
(4.32)\end{array}$ & $\begin{array}{c}-3.42 * * \\
(1.18)\end{array}$ & $\begin{array}{c}0.02 \\
(1.39)\end{array}$ & $\begin{array}{l}-1.59 \\
(1.99)\end{array}$ & $\begin{array}{l}-1.84 \\
(1.36)\end{array}$ \\
\hline $\begin{array}{l}\text { Parental education } \\
\text { Neither parent completed } \\
\text { upper secondary education }\end{array}$ & Ref. & Ref. & Ref. & Ref. & Ref. & Ref. & Ref. \\
\hline $\begin{array}{l}\text { At least one parent } \\
\text { completed upper } \\
\text { secondary education }\end{array}$ & $\begin{array}{c}0.16 \\
(1.06)\end{array}$ & $\begin{array}{c}4.26 * * * \\
(0.96)\end{array}$ & $\begin{array}{c}3.75 * * * \\
(0.86)\end{array}$ & $\begin{array}{l}3.54 * * \\
(1.19)\end{array}$ & $\begin{array}{c}0.53 \\
(1.21)\end{array}$ & $\begin{array}{l}2.50 * \\
(1.05)\end{array}$ & $\begin{array}{c}1.24 \\
(1.28)\end{array}$ \\
\hline $\begin{array}{l}\text { At least one parent } \\
\text { completed tertiary } \\
\text { education }\end{array}$ & $\begin{array}{c}1.02 \\
(1.18)\end{array}$ & $\begin{array}{c}7.30 * * * \\
(1.91)\end{array}$ & $\begin{array}{c}9.90 * * * \\
(1.94)\end{array}$ & $\begin{array}{l}3.16+ \\
(1.65)\end{array}$ & $\begin{array}{l}3.06^{*} \\
(1.24)\end{array}$ & $\begin{array}{c}2.22 \\
(1.77)\end{array}$ & $\begin{array}{c}2.23 \\
(1.44)\end{array}$ \\
\hline \multicolumn{8}{|l|}{$\begin{array}{l}\text { Potential work } \\
\text { experience } \\
\text { (Linear splines) }\end{array}$} \\
\hline $0-10$ & $\begin{array}{l}0.47 * * \\
(0.16)\end{array}$ & $\begin{array}{l}0.32+ \\
(0.17)\end{array}$ & $\begin{array}{l}0.39 * \\
(0.20)\end{array}$ & $\begin{array}{l}-0.08 \\
(0.20)\end{array}$ & $\begin{array}{l}0.59 * * \\
(0.18)\end{array}$ & $\begin{array}{c}0.16 \\
(0.18)\end{array}$ & $\begin{array}{l}0.45+ \\
(0.26)\end{array}$ \\
\hline $10-20$ & $\begin{array}{c}0.20 \\
(0.17)\end{array}$ & $\begin{array}{c}0.07 \\
(0.15)\end{array}$ & $\begin{array}{c}0.01 \\
(0.15)\end{array}$ & $\begin{array}{c}0.09 \\
(0.14)\end{array}$ & $\begin{array}{l}0.60^{* * *} \\
(0.18)\end{array}$ & $\begin{array}{l}0.43^{*} \\
(0.18)\end{array}$ & $\begin{array}{c}0.21 \\
(0.17)\end{array}$ \\
\hline $20-30$ & $\begin{array}{c}0.18 \\
(0.17)\end{array}$ & $\begin{array}{l}-0.07 \\
(0.14)\end{array}$ & $\begin{array}{c}0.16 \\
(0.14)\end{array}$ & $\begin{array}{c}0.00 \\
(0.13)\end{array}$ & $\begin{array}{l}-0.22 \\
(0.20)\end{array}$ & $\begin{array}{l}-0.28 \\
(0.18)\end{array}$ & $\begin{array}{l}0.05 \\
(0.17)\end{array}$ \\
\hline $30+$ & $\begin{array}{l}-0.52+ \\
(0.31)\end{array}$ & $\begin{array}{l}-0.08 \\
(0.24)\end{array}$ & $\begin{array}{l}-0.27 \\
(0.24)\end{array}$ & $\begin{array}{l}-0.04 \\
(0.14)\end{array}$ & $\begin{array}{c}0.24 \\
(0.36)\end{array}$ & $\begin{array}{c}0.19 \\
(0.25)\end{array}$ & $\begin{array}{c}0.21 \\
(0.28)\end{array}$ \\
\hline $\begin{array}{l}\text { Self-employed } \\
\text { No }\end{array}$ & & & & & & & \\
\hline $\begin{array}{l}\text { No } \\
\text { Yes }\end{array}$ & $\begin{array}{l}\text { Ref. } \\
-4.09 * \\
(1.71)\end{array}$ & $\begin{array}{l}\text { Ref. } \\
-1.64 \\
(1.02)\end{array}$ & $\begin{array}{l}\text { Ref. } \\
10.11 * * * \\
(1.18)\end{array}$ & $\begin{array}{l}\text { Ref. } \\
5.79^{* * * *} \\
(1.15)\end{array}$ & $\begin{array}{l}\text { Ref. } \\
1.33 \\
(1.73)\end{array}$ & $\begin{array}{l}\text { Ref. } \\
-0.01 \\
(1.33)\end{array}$ & $\begin{array}{l}\text { Ref. } \\
-1.34 \\
(1.50)\end{array}$ \\
\hline Constant & $\begin{array}{c}30.79 * * * \\
(1.43)\end{array}$ & $\begin{array}{l}27.91 * * * \\
(1.36)\end{array}$ & $\begin{array}{l}29.87 * * * \\
(1.67)\end{array}$ & $\begin{array}{c}36.52 * * * \\
(1.76)\end{array}$ & $\begin{array}{l}28.19 * * * \\
(1.52)\end{array}$ & $\begin{array}{l}35.29 * * * \\
(1.54)\end{array}$ & $\begin{array}{c}33.07 * * * \\
(2.58)\end{array}$ \\
\hline $\begin{array}{l}\mathrm{N} \\
\mathrm{R} 2\end{array}$ & $\begin{array}{l}1545 \\
0.12\end{array}$ & $\begin{array}{c}2969 \\
0.10\end{array}$ & $\begin{array}{c}2474 \\
0.15\end{array}$ & $\begin{array}{c}2247 \\
0.14\end{array}$ & $\begin{array}{l}1470 \\
0.13\end{array}$ & $\begin{array}{c}2808 \\
0.14\end{array}$ & $\begin{array}{l}1620 \\
0.13\end{array}$ \\
\hline
\end{tabular}

Notes: Multiple imputation estimates (10 imputations/plausible values). Survey weights applied. Standard errors in parentheses. Literacy and numeracy skills are z-standardized. $+\mathrm{p}<0.10, * \mathrm{p}<0.05, * * \mathrm{p}<0.01$. ISEI $=$ International Socio-Economic Index of Occupational Status. ISCED = International Standard Classification of Education. Ref. = Reference category.

Source: PIAAC 2011/12, authors' calculations. 


\section{APPENDIX B. COUNTRY-LEVEL RESULTS WITH NON- EMPLOYED RESPONDENTS DROPPED FROM THE SAMPLE}

The sample used in the main analysis includes respondents who were not employed at the time of interview, but had left their last job no more than five years ago. For these respondents, occupation codes and hence also ISEI scores refer to the last rather than the current job. In Table B1 we reestimate the sequence of country-level regressions reported in Table 4 in the main article with non-employed respondents removed from the sample. Reassuringly, results tend to be even clearer than in the main analysis with larger effect sizes (in absolute terms) and smaller p-values.

Table B1. Country-level regressions of ISEI gap on measures of skills transparency and vocational orientation (sample restricted to respondents who were employed at the time of interview)

\begin{tabular}{lccccccc}
\hline & Model 1 & Model 2 & Model 3 & Model 4 & Model 5 & Model 6 & Model 7 \\
\hline Skills gap & $-1.073^{*}$ & & & $-1.311^{* *}$ & $-1.334^{* *}$ & & $-1.511^{* * *}$ \\
& $(0.478)$ & & & $(0.395)$ & $(0.437)$ & & $(0.354)$ \\
Index of internal homogeneity & & $-1.025^{*}$ & & $-1.248^{* *}$ & & $-0.921+$ & $-1.159^{* *}$ \\
& & $(0.477)$ & & $(0.406)$ & & $(0.473)$ & $(0.354)$ \\
Index of vocational orientation & & & -0.785 & & $-1.111^{*}$ & -0.621 & $-0.981^{*}$ \\
& & & $(0.509)$ & & $(0.445)$ & $(0.484)$ & $(0.371)$ \\
Intercept & $-5.465^{* * *}$ & $-5.459^{* * *}$ & $-5.467 * * *$ & $-5.462^{* * *}$ & $-5.480^{* * *}$ & $-5.462^{* * *}$ & $-5.473^{* * *}$ \\
& $(0.459)$ & $(0.459)$ & $(0.483)$ & $(0.383)$ & $(0.411)$ & $(0.451)$ & $(0.338)$ \\
$N$ & 21 & 21 & 21 & 21 & 21 & 21 & 21 \\
$R 2$ & 0.22 & 0.20 & 0.11 & 0.51 & 0.43 & 0.27 & 0.66 \\
Adjusted R2 & 0.18 & 0.16 & 0.07 & 0.46 & 0.37 & 0.19 & 0.60 \\
\hline
\end{tabular}

Note: Feasible Generalized Least Squares estimates following Lewis and Linzer (2005), based on 10 imputations/plausible values. The dependent variable is the ISEI gap between less-educated (ISCED categories 0-2) and intermediate-educated (ISCED categories 3/4) adults aged 16-54. The ISEI gap measures the occupational status of less-educated adults compared to intermediate educated adults, so more negative values correspond to a larger disadvantage for the less-educated group. ISEI gap is estimated using country-specific individual-level regressions that control for literacy and numeracy skills, sex, potential work experience, foreignbirth/foreign-language status, parental educational attainment, self-employment status (referred to as the "fully adjusted status gap" in the text). All predictors are z-standardized (mean of 0 , standard deviation of 1 ). Standard errors in parentheses. $+\mathrm{p}<0.1, * \mathrm{p}<0.05, * * \mathrm{p}<0.01, * * * \mathrm{p}<0.001$ (two-tailed tests).

Sources: PIAAC 2011/2012, authors' calculations. 


\section{APPENDIX C. COUNTRY-LEVEL RESULTS WITH SELF- EMPLOYED RESPONDENTS DROPPED FROM THE SAMPLE}

The sample used in the main analysis includes wage and salary workers as well as selfemployed respondents. Signaling/screening theories may, however, appear to be most directly applicable to hiring processes for wage and salary workers. On the other hand, customers may also statistically discriminate against the self-employed. The extent of statistical discrimination against wage and salary workers might also indirectly affect selection into selfemployment by influencing the opportunity costs of self-employment (the foregone opportunities as a wage and salary worker). These considerations suggest that there is no clear best way of treating self-employed respondents. As a straightforward robustness check, we therefore reestimate the sequence of country-level regressions reported in Table 4 in the main article with self-employed respondents excluded from the sample.

Coefficient estimates for the skills gap and the index of internal homogeneity are similar to those found in the main analysis. In particular, both remain statistically significant at the five percent level or better in our preferred specification (Model 7 in Table 4 in the main article and in Table $\mathrm{C} 1$ below), with the former being slightly larger and the latter slightly smaller (again, in absolute size) than in the main analysis. The effect of the vocational orientation index is noticeably weaker when we drop self-employed respondents from the analysis (-.592 in Model 7 in Table C1, as opposed to -.744 in Table 4 in the main article) and no longer statistically significant $(\mathrm{p}=.13)$.

Further analysis suggests that the attenuation of the coefficient of vocational orientation has two main sources. First, the rate of self-employment among the less educated decreases with the extent of vocational orientation and, second, self-employment is positively associated with occupational status among people with the same level of education. A likely explanation for this pattern is that access to self-employment in certain (relatively skilled) occupations tends to be more strongly regulated in countries with a stronger vocational orientation. In particular, having (at least) intermediate-level formal qualifications is often a prerequisite for establishing a business in certain occupations, effectively barring less-educated people from doing so. 
Table C1. Country-level regressions of occupational status gap on measures of skills transparency and vocational orientation. Respondents who were/are selfemployed in their last/current job excluded from the analysis.

\begin{tabular}{lccccccc}
\hline & Model 1 & Model 2 & Model 3 & Model 4 & Model 5 & Model 6 & Model 7 \\
\hline Skills gap & $-0.905^{*}$ & & & $-1.063^{*}$ & $-1.077^{*}$ & & $-1.178^{* *}$ \\
& $(0.419)$ & & & $(0.365)$ & $(0.407)$ & & $(0.359)$ \\
Index of internal homogeneity & & $-0.786+$ & & $-0.957 *$ & & -0.723 & $-0.867^{*}$ \\
& & $(0.423)$ & & $(0.372)$ & & $(0.435)$ & $(0.360)$ \\
Index of vocational orientation & & & -0.472 & & $-0.739+$ & -0.324 & -0.592 \\
& & & $(0.455)$ & & $(0.411)$ & $(0.445)$ & $(0.371)$ \\
Intercept & $-5.690 * * *$ & $-5.692^{* * *}$ & $-5.693 * * *$ & $-5.688^{* * *}$ & $-5.690^{* * *}$ & $-5.691^{* * *}$ & $-5.687 * * *$ \\
& $(0.405)$ & $(0.412)$ & $(0.436)$ & $(0.357)$ & $(0.385)$ & $(0.417)$ & $(0.344)$ \\
$N$ & 21 & 21 & 21 & 21 & 21 & 21 & 21 \\
R2 & 0.21 & 0.16 & 0.05 & 0.43 & 0.33 & 0.18 & 0.51 \\
Adjusted R2 & 0.16 & 0.11 & 0.01 & 0.37 & 0.26 & 0.09 & 0.42 \\
\hline
\end{tabular}

Note: Feasible Generalized Least Squares estimates following Lewis and Linzer (2005), based on 10 imputations/plausible values. The dependent variable is the ISEI gap between less-educated (ISCED categories 0-2) and intermediate-educated (ISCED categories 3/4) adults aged 16-54. The ISEI gap measures the occupational status of less-educated adults compared to intermediate educated adults, so more negative values correspond to a larger disadvantage for the less-educated group. ISEI gap is estimated using country-specific individual-level regressions that control for literacy and numeracy skills, sex, potential work experience, foreignbirth/foreign-language status, parental educational attainment, self-employment status (referred to as the "fully adjusted status gap" in the text). All predictors are z-standardized (mean of 0 , standard deviation of 1). Standard errors in parentheses. $+\mathrm{p}<0.1, * \mathrm{p}<0.05, * * \mathrm{p}<0.01, * * * \mathrm{p}<0.001$ (two-tailed tests).

Sources: PIAAC 2011/2012, authors' calculations. 


\section{APPENDIX D. CONSEQUENCES OF ASSIGNING OCCUPATIONAL STATUS BASED ON MORE DETAILED OCCUPATION CODES}

For the main analysis, we assigned ISEI scores on the basis of one-digit (ISCO 2008) occupation codes. One-digit codes group workers into ten broad occupational categories. It would be preferable to assign occupational status using more fine-grained occupational categories, but unfortunately four countries in our sample only provide one-digit codes in their PIAAC public use file. In this section, we explore the consequences of using two-digit occupational codes for the 17 countries where these are available.

Figure D1 plots the fully adjusted ISEI gaps based on one-digit (x-axis) and two-digit (y axis) for these 17 countries. Reassuringly, estimated ISEI gaps based on two-digit codes are very similar to the one-digit case throughout. The Pearson correlation between the two measures is 99.

To further check the robustness of our results, we also repeated the country-level regressions reported in Table 4 in the main article with ISEI gaps based on two-digit codes as the dependent variable. To separate the effect of using more detailed occupation codes from the effect of dropping the four countries that do not provide two-digit codes (Austria, Canada, Estonia, Finland), we first show results based on one-digit occupational for the reduced country sample (Table D1). Table D2 then reports results based on two-digit occupational codes.

Comparison of Tables A1 and A2 reveals that using two-digit occupation codes has negligible effects the estimated coefficients and their statistical significance. Moreover, coefficient estimates for the skills gap and the index of internal homogeneity are very similar to those found in the main analysis (cf. Table 4 in the main article). Despite the considerable reduction of the country-level sample, they also remain statistically significant at the ten percent level or better. The estimated effect of the vocational orientation index is weaker in Tables D1 and D2 than in the main analysis, at -.540 (Table D1) and -.581 (Table D2) rather than -.744. It also fails to attain statistical significance. However, attenuation occurs already in Table D1 (and the effect is even slightly stronger in Table D2 than in Table D1). It is therefore clearly attributable to the reduction of the country sample rather than to the use of more detailed occupational categories. 
Figure D1. ISEI gap based on one- and two-digit occupational codes

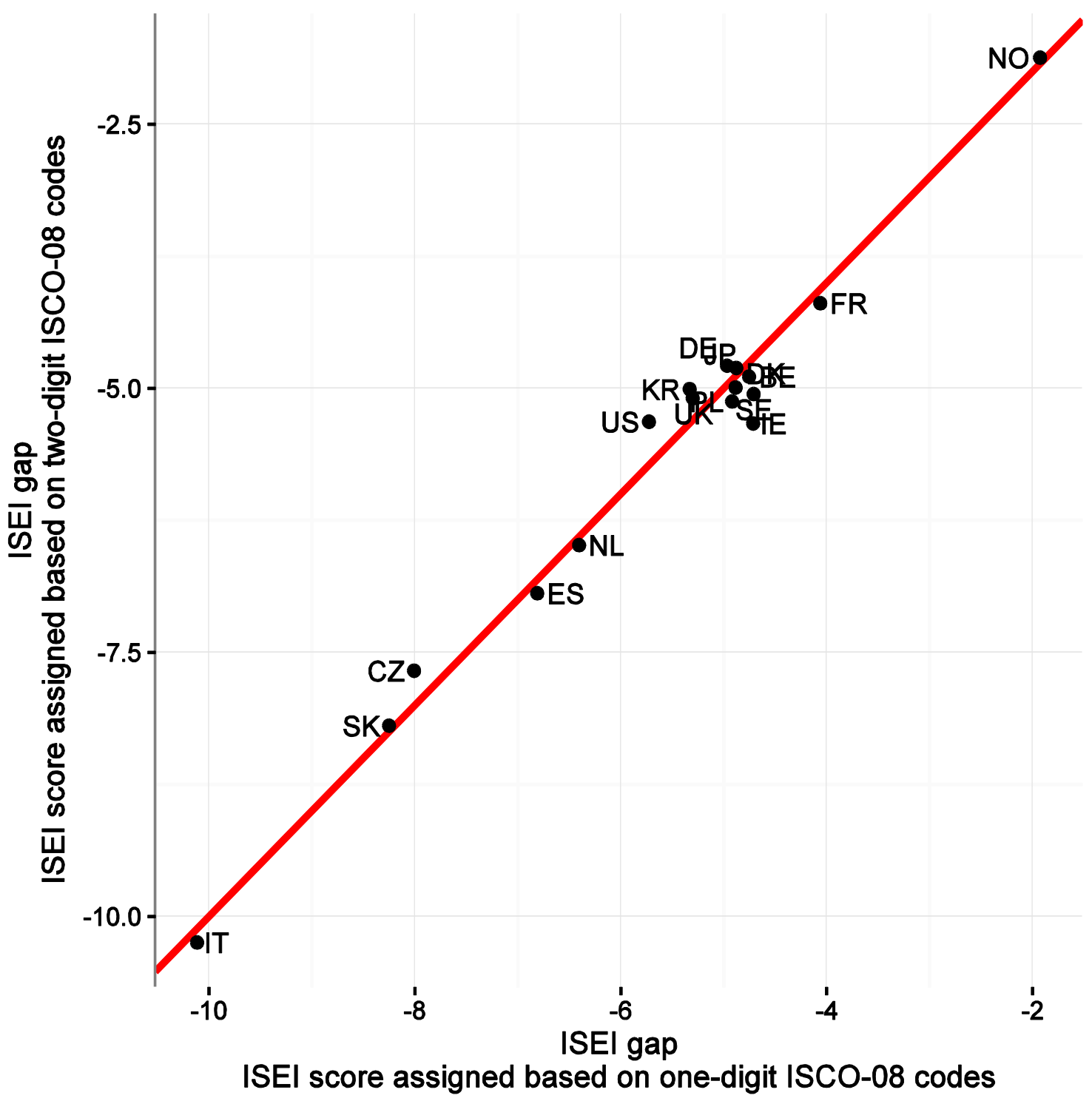

Notes: Estimated ISEI gaps between less-educated (ISCED categories 0-2) and intermediate-educated (ISCED categories 3-4) adults aged 16-54 for the 17 countries that provide two-digit in addition to one-digit occupation codes. The ISEI gap measures the occupational status of less-educated adults compared to intermediate educated adults, so more negative values correspond to a larger disadvantage for the less-educated group. The ISEI gap is estimated using country-specific individual-level regressions that control for literacy and numeracy skills, sex, potential work experience, foreign-birth/foreign-language status, parental educational attainment, selfemployment sta tus (referred to as the "fully adjusted status gap" in the text) (see Section A in the online appendix).

The figure illustrates how the country-specific estimates of the ISEI gap differ when ISEI scores are assigned on the basis of one-digit (x-axis) and two-digit (y-axis) occupation codes respectively. For the country codes, see Table 2 in the main article.

Sources: PIAAC 2011/2012, authors' calculations. 
Table D1. Country-level regressions with ISEI gap based on one-digit occupational codes as dependent variable (sample restricted to the 17 countries where twodigit codes are also available; Austria, Canada, Estonia, Finland dropped)

\begin{tabular}{lccccccc}
\hline & Model 1 & Model 2 & Model 3 & Model 4 & Model 5 & Model 6 & Model 7 \\
\hline Skills gap & $-1.098^{*}$ & & & $-1.200^{*}$ & $-1.091+$ & & $-1.184^{*}$ \\
& $(0.503)$ & & & $(0.438)$ & $(0.497)$ & & $(0.432)$ \\
Index of internal homogeneity & & $-0.793+$ & & $-0.884^{*}$ & & -0.780 & $-0.878^{*}$ \\
& & $(0.443)$ & & $(0.381)$ & & $(0.439)$ & $(0.370)$ \\
Index of vocational orientation & & & -0.588 & & -0.571 & -0.559 & -0.540 \\
& & & $(0.546)$ & & $(0.492)$ & $(0.518)$ & $(0.441)$ \\
Intercept & $-5.602^{* * *}$ & $-5.578^{* * *}$ & $-5.591^{* * *}$ & $-5.547^{* * *}$ & $-5.563^{* * *}$ & $-5.541^{* * *}$ & $-5.510^{* * *}$ \\
& $(0.423)$ & $(0.438)$ & $(0.465)$ & $(0.373)$ & $(0.420)$ & $(0.436)$ & $(0.367)$ \\
$N$ & 17 & 17 & 17 & 17 & 17 & 17 & 17 \\
R2 & 0.26 & 0.18 & 0.07 & 0.48 & 0.33 & 0.25 & 0.54 \\
Adjusted R2 & 0.21 & 0.12 & 0.01 & 0.41 & 0.23 & 0.14 & 0.44 \\
\hline
\end{tabular}

Table D2. Country-level regressions with ISEI gap based on two-digit occupational codes as dependent variable (Austria, Canada, Estonia, Finland dropped because two-digit codes are unavailable)

\begin{tabular}{lccccccc}
\hline & Model 1 & Model 2 & Model 3 & Model 4 & Model 5 & Model 6 & Model 7 \\
\hline Skills gap & $-1.040+$ & & & $-1.136^{*}$ & $-1.036+$ & & $-1.125^{*}$ \\
& $(0.512)$ & & & $(0.463)$ & $(0.504)$ & & $(0.455)$ \\
Index of internal homogeneity & & -0.710 & & $-0.800+$ & & -0.696 & $-0.791+$ \\
& & $(0.449)$ & & $(0.398)$ & & $(0.444)$ & $(0.386)$ \\
Index of vocational orientation & & & -0.623 & & -0.612 & -0.596 & -0.583 \\
& & & $(0.539)$ & & $(0.493)$ & $(0.521)$ & $(0.456)$ \\
Intercept & $-5.627 * * *$ & $-5.611^{* * *}$ & $-5.618 * * *$ & $-5.575^{* * *}$ & $-5.589^{* * *}$ & $-5.574^{* * *}$ & $-5.540^{* * *}$ \\
& $(0.427)$ & $(0.444)$ & $(0.460)$ & $(0.390)$ & $(0.421)$ & $(0.440)$ & $(0.382)$ \\
$N$ & 17 & 17 & 17 & 17 & 17 & 17 & 17 \\
$R 2$ & 0.23 & 0.15 & 0.08 & 0.42 & 0.31 & 0.22 & 0.49 \\
Adjusted R2 & 0.18 & 0.09 & 0.02 & 0.34 & 0.21 & 0.11 & 0.37 \\
\hline
\end{tabular}

Note (for both tables): Feasible Generalized Least Squares estimates following Lewis and Linzer (2005), based on 10 imputations/plausible values. The dependent variable is the ISEI gap between less-educated (ISCED categories 0-2) and intermediate-educated (ISCED categories 3/4) adults aged 16-54. The ISEI gap measures the occupational status of less-educated adults compared to intermediate educated adults, so more negative values correspond to a larger disadvantage for the less-educated group. ISEI gap is estimated using country-specific individual-level regressions that control for literacy and numeracy skills, sex, potential work experience, foreignbirth/foreign-language status, parental educational attainment, self-employment status (referred to as the "fully adjusted status gap" in the text). All predictors are z-standardized (mean of 0, standard deviation of 1). Standard errors in parentheses. $+\mathrm{p}<0.1, * \mathrm{p}<0.05, * * \mathrm{p}<0.01$, *** $\mathrm{p}<0.001$ (two-tailed tests).

Sources: PIAAC 2011/2012, authors' calculations. 


\section{APPENDIX E. OUTLIER ANALYSIS}

To assess the possibility that the country-level results are strongly influenced by single country cases, we repeatedly reestimated our preferred specification (Model 7 in Table 4 in the main article), omitting one country at a time. The resulting coefficient estimates are depicted in Figure E1. The dashed vertical lines represent the full sample point estimate and the dark (light) grey shaded areas the associated 90\% (95\%) confidence intervals. The dots represent the coefficient estimates after excluding the country indicated on the left from the sample. The associated 90\% (95\%) confidence intervals are indicated by thick (thin) horizontal bars.

The results of this outlier analysis are very reassuring. There is not a single case where dropping a country dramatically changes the estimate of one of the three coefficients. Moreover, the estimated effects of the skills gap and the index of internal homogeneity always remain statistically significance at the five percent level (the 95\% confidence intervals never cross the zero line). For the vocational orientation index, we find only one case where the coefficient estimate is no longer statistically significant at the ten percent level. This occurs when Korea is dropped from the sample (the two-sided p-value is .104). 
Figure E1. Coefficient estimates with one country omitted at a time (based on Model 7 in Table 4 in the main article)

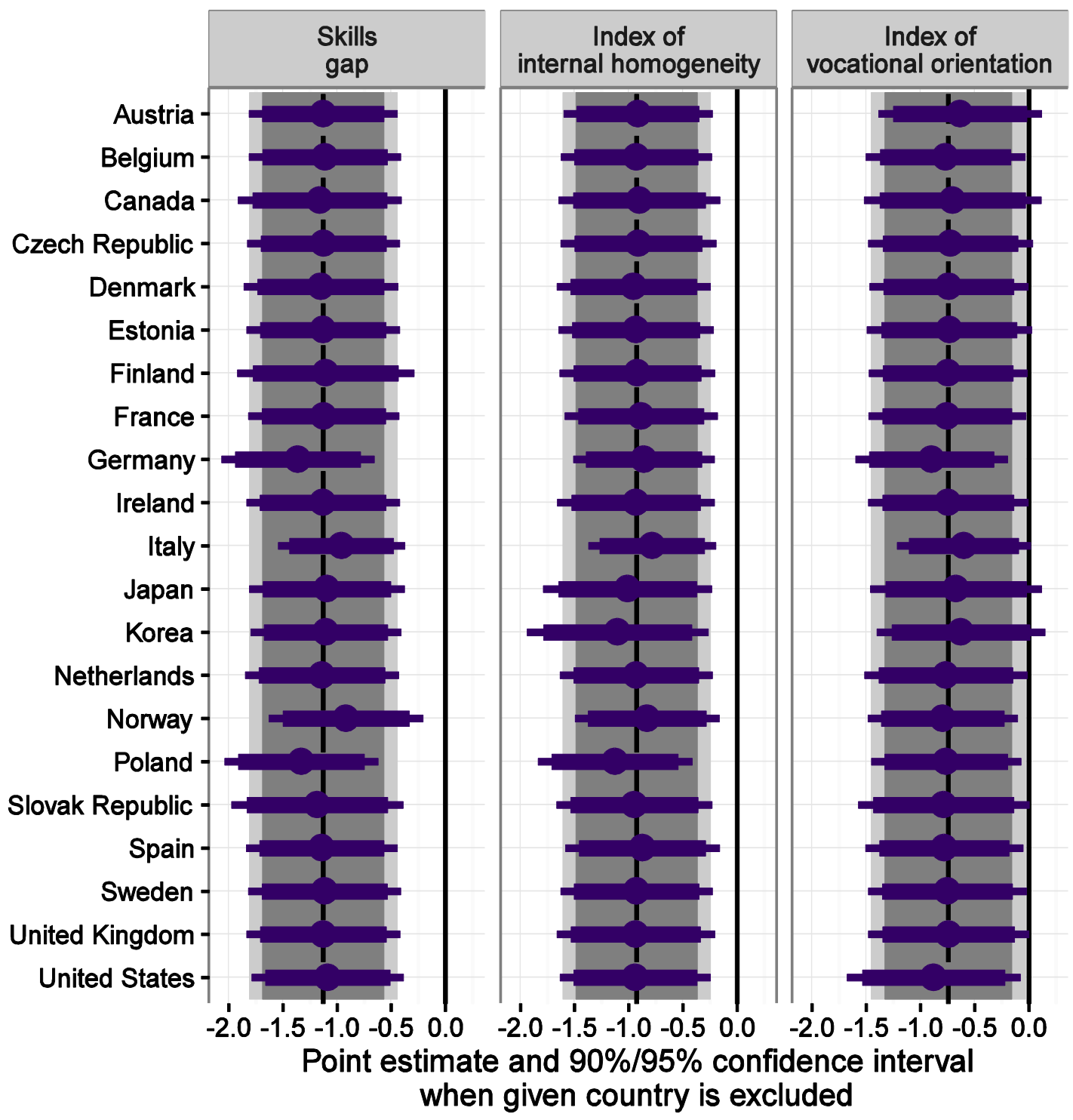

Notes: Dashed vertical lines represent full sample point estimates and dark (light) shaded areas the associated 90\% (95\%) confidence intervals. Dots represent point estimates with given country removed from the sample. Thick (thin) horizontal lines indicate the associated 90\% (95\%) confidence intervals.

Source: PIAAC 2011/12, authors' calculations. 